\title{
A multiple case history and systematic review of adoption, diffusion, implementation and impact of provincial daily physical activity policies in Canadian schools
}

Dana Lee Olstad ${ }^{1}$, Elizabeth J Campbell ${ }^{2}$, Kim D Raine ${ }^{2}$ and Candace IJ Nykiforuk 2* $^{*}$

\begin{abstract}
Background: Few children meet physical activity (PA) recommendations, and are therefore at increased risk for overweight/obesity and adverse health outcomes. To increase children's opportunities for PA, several Canadian provinces have adopted school-based daily PA (DPA) policies. It is not clear why some jurisdictions have adopted DPA policies, and others have not, nor whether these policies have been implemented and have achieved their intended outcomes. The purpose of this study was to understand the processes underlying adoption and diffusion of Canadian DPA policies, and to review evidence regarding their implementation and impact.

Methods: We adopted a multiple case history methodology in which we traced the chronological trajectory of DPA policies among Canadian provinces by compiling timelines detailing key historical events that preceded policy adoption. Publicly available documents posted on the internet were reviewed to characterize adopter innovativeness, describe the content of their DPA policies, and explore the context surrounding policy adoption. Diffusion of Innovations theory provided a conceptual framework for the analyses. A systematic literature search identified studies that had investigated adoption, diffusion, implementation or impact of Canadian DPA policies.

Results: Five of Canada's 13 provinces and territories (38.5\%) have DPA policies. Although the underlying objectives of the policies are similar, there are clear differences among them and in their various policy trajectories. Adoption and diffusion of DPA policies were structured by the characteristics and capacities of adopters, the nature of their policies, and contextual factors. Limited data suggests implementation of DPA policies was moderate but inconsistent and that Canadian DPA policies have had little to no impact on school-aged children's PA levels or BMI.

Conclusions: This study detailed the history and current status of Canadian DPA policies, highlighting the conditional nature of policy adoption and diffusion, and describing policy and adopter characteristics and political contexts that shaped policy trajectories. An understanding of the conditions associated with successful policy adoption and diffusion can help identify receptive contexts in which to pioneer novel legislative initiatives to increase PA among children. By reviewing evidence regarding policy implementation and impact, this study can also inform amendments to existing, and development of future PA policies.
\end{abstract}

Keywords: Physical activity, Policy, Diffusion, Adoption, Implementation, Impact, Systematic review, Children, School

\footnotetext{
* Correspondence: candace.nykiforuk@ualberta.ca

${ }^{2}$ School of Public Health, 3-300 Edmonton Clinic Health Academy, University

of Alberta, 1140587 Avenue, Edmonton, AB T6G 1C9, Canada

Full list of author information is available at the end of the article
} 


\section{Background}

Children who engage in 60 minutes of moderate-tovigorous physical activity (MVPA) daily are less likely to be overweight/obese and to exhibit risk factors for chronic disease [1]. For this reason, Health Canada [2,3] and other national governments [4] recommend that children accumulate at least 60 minutes of MVPA daily. Many Canadian children are not sufficiently active to achieve health benefits, however, as only $8 \%$ of boys and $4 \%$ of girls aged 6-17 meet Canadian physical activity (PA) guidelines [5]. Youth report that many of the barriers they face with respect to PA are environmental, in that they perceive having insufficient time, opportunity and resources to be more physically active $[6,7]$.

School-based initiatives provide an opportunity to reach children at a critical time point, as they are developing attitudes and behaviors that may influence their future health [8]. Schools are particularly suited for PA interventions because children already spend a substantial amount of time there, they have existing PA-related infrastructure, and they require most students to engage in some amount of PA through Physical Education (PE) courses. However, although children who participate in $\mathrm{PE}$ are more physically active than their counterparts [9-12], Canadian children spend $<15 \%$ of their PE time in MVPA [13], and cost-cutting measures have reduced the overall quality and quantity of PE provided [14-18]. In high schools, enrollment in PE has declined over time [19] and declines at higher grades to levels as low as $29 \%$ in some cases $[9,16,19,20]$. Similar trends have been identified in the US, where children are spending more time in sedentary, academic pursuits and less time in PE and recess as a result of legislation associated with 'No Child Left Behind' [21-23]. Thus, school-based PE classes as currently offered may not provide children and youth with sufficient PA opportunities.

Public policy has potential to increase children's PA participation in schools. By enacting policy, governments can effectively and equitably create school environments that support PA with little effort on the part of children [24]. Evidence suggests that policies that require participation in, or that specify minimum time requirements for $\mathrm{PE}$ have been effective in increasing the amount of PE offered in schools [25-27], in increasing student attendance to PE class [28], PA levels [28,29], and physical fitness [30]. Furthermore, increased time spent in PE/PA does not compromise, and may even improve academic performance [31-35]. School-based PA policies may offer similar benefits as PE policies, although few studies exist [36].

To increase children's opportunities for PA, several Canadian provinces and US states have adopted schoolbased daily PA (DPA) policies. These policies stipulate minimum PA time requirements for children and youth during, and in some cases also outside of, school hours.
Schools and School Boards may enact their own policies provided they meet or exceed these minimum provincial/state standards. It is not clear why some jurisdictions have adopted DPA policies, while others have not. The impetus for policy change can originate within a polity, such as when interests groups coalesce around an issue and advocate for change [37]. Alternatively policy adoption can also be stimulated through processes of diffusion [38], in which governments learn from the experiences of other jurisdictions, rather than develop their own novel policies for each specific issue [37-39]. Policy diffusion is a common phenomenon. Just as diffusion of tobacco control legislation helped to de-normalize tobacco consumption [38], diffusion of school-based DPA policies has potential to inspire widespread normative change related to children's PA opportunities. An understanding of DPA policy trajectories can inform efforts to stimulate and accelerate policy adoption among jurisdictions that have been resistant or slow to adopt such policies. Policy disparities can lead to differential child health outcomes, underscoring the need to examine the articulation of PA policies across Canada [38].

Policy adoption and diffusion are not discrete and bounded events, but rather context-sensitive processes that unfold over time. While previous investigations have explored cross-sectional predictors of PA-related policy adoption and diffusion [40-43], few have investigated the processes underlying these outcomes, and none to our knowledge have focused on DPA policies in schools. Furthermore, the level of implementation and impact of these policies within the Canadian context has not been synthesized. Thus, the purpose of this study was to understand the processes underlying adoption and diffusion of Canadian provincial/territorial DPA policies, and to review evidence regarding their implementation and impact.

\section{Methods \\ Study design}

To understand the dynamics surrounding adoption and diffusion of DPA policies, we adopted a multiple case history methodology in which we traced the chronological trajectory of DPA policies among Canadian provinces by compiling timelines detailing key historical events that preceded policy adoption [44]. Diffusion of Innovations theory provided an organizing conceptual framework for the analyses [45]. The theory posits that the key characteristics of adopters (i.e. their innovativeness, as reflected by their position in a diffusion curve), of the innovation, and key contextual factors such as communication channels and social networks are strong determinants of adoption [45]. Similarly, Shipan and Volden [39] propose that policy diffusion is conditioned on the nature of policies, characteristics and capacities of adopters, and contextual factors. Accordingly, the current analysis characterizes adopters based on their 
degree of innovativeness, describes the content of their DPA policies, and the context surrounding policy adoption. To complete the policy cycle, we performed a systematic review of studies that have evaluated adoption, diffusion, implementation or impact of school-based Canadian DPA policies.

\section{Data collection Identification of adopters}

First, websites of the Ministries of Education in each Canadian province/territory were searched to determine which jurisdictions had school-based DPA policies, and the time of policy adoption and implementation. We searched the Lexis Nexis Legislation database [46] and the Prevention Policies Directory [47] to identify DPA policies that may have been missed, or that had been proposed but not enacted. A jurisdiction was considered to have a DPA policy if it had statutory legislation (laws enacted by a provincial legislature) or administrative laws (rules and regulations developed by provincial ministries) specifying PA time requirements for school-aged children that were administered at the school level $[26,48]$. These jurisdictions are hereafter referred to as 'adopters'. Jurisdictions without DPA policies, or with PE policies that did not specify minimum PA time requirements were designated as 'nonadopters'. Within non-adopter provinces/territories there may have been smaller jurisdictions that had adopted DPA policies, however we limited our review to those that were enacted at the provincial level (i.e. province-wide).

\section{Policy content and context}

Once adopters were identified, government websites provided a starting point to understand the content of the various policies, the context within which they were developed and implemented, and to locate additional DPArelated documents, including guidelines, implementation plans, memoranda, policy frameworks and strategies, school curricula, action plans, newsletters, press releases, evaluations, and other documents related to the genesis and evolution of DPA policies over time. General webbased searches helped to locate additional documents. Once relevant sources were identified, we used a snowballing procedure to follow links within these documents to others that were of interest. Given the breadth of the search processes and terms, we did not attempt to record or screen all hits or the number of documents reviewed, and focused instead on retrieving and reviewing all documents that described polices or programs related to PA and/or healthy living initiatives in schools [44]. We requested 2 Alberta-based documents that had been cited, but were no longer available online from report authors.

This body of evidence was used to construct a comprehensive timeline for each adopter on which we plotted key policy cycle-related events (e.g. policy adoption and implementation) relative to key contextual events (e.g. major reports, activities of advocacy groups), spanning the earliest located reference to PA promotion in schools, to the present day (i.e. August, 2014). We contacted government officials to clarify the information contained within some documents, and to confirm the specific timing of adoption and implementation of all policies. No provincial ministries could confirm dates on which DPA policies were adopted; therefore, the public announcement date for each policy was used as the proxy date for policy adoption. In all cases, policies were publicly announced prior to their implementation. An independent reviewer subsequently reviewed all documents in each timeline to determine which documents to retain in the final analysis using a more targeted set of criteria. Specifically, documents were excluded that were unrelated to the role of schools in provision of PA/ $\mathrm{PE}$, had not been mentioned within other sources as having informed DPA policy-related activities, or for which there was no clear evidence of a contribution to placing PA in schools on the policy agenda. In addition, timelines were truncated according to the date of DPA policy adoption. A total of 59 documents were included in the final provincial timelines.

\section{Policy evaluation}

Next, a systematic search was performed to identify studies that had evaluated any aspect of school-based DPA policies. An information specialist designed and executed the search using a scoping review framework [49]. Electronic databases (Ovid Medline, Ovid PsycINFO, Ovid ERIC, and SPORTDiscus with Full Text via EBSCOhost) were searched using subject headings and text words for concepts related to policies, schools, and PA (Additional file 1). Database searches were limited to English and French references published between 2003 and August, 2014. A total of 1086 citations were identified through these searches, with an additional 844 identified by checking websites for known research centers (Rudd Center for Food Policy and Obesity, Bridging the Gap, and Active Living Research) and from reference lists from key systematic and literature reviews. Websites of groups known to be conducting, or to have conducted PA-related research in Canadian schools were also hand searched to identify additional DPA-related studies (Compass, SHAPES, Healthy Kids, Living School, People for Education, Active Schools! BC). These sources did not yield additional articles for the systematic review, although they did yield documents for the broader document review. Following removal of duplicate records, 917 unique citations remained (Figure 1).

A single reviewer examined all titles and/or abstracts to remove irrelevant studies. Articles were eligible for inclusion if they met the following criteria: 1) Original research study published in a peer-reviewed journal in English or 


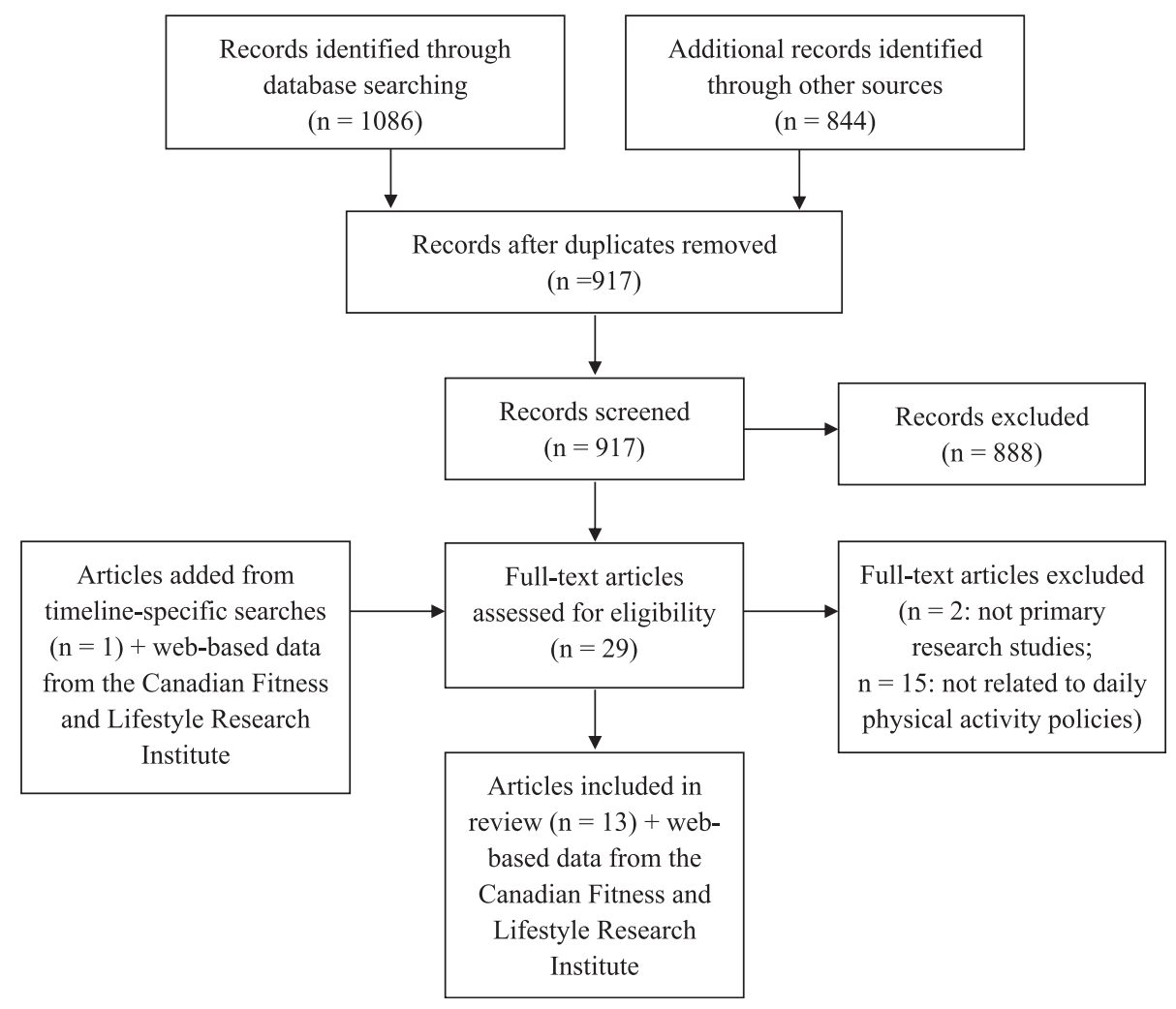

Figure 1 PRISMA flow diagram.

French; and 2) Evaluated adoption, diffusion, implementation or impact of school-based DPA policies in Canada. The entire article was retrieved and screened if abstracts were not available or were not sufficiently detailed. Two reviewers, working independently, then examined the full text of the remaining articles $(n=29)$ for compliance with inclusion criteria. Disagreements were resolved through consensus discussion. Two papers were excluded because they were not primary research studies, while 15 were excluded because they did not concern Canadian DPA policies. Supplemental searches of reference lists of included papers and of related reviews and commentaries identified 1 additional article, along with web-based data from the Canadian Fitness and Lifestyle Research Institute describing objective measures of children's PA levels by province. Although not published in a peer-reviewed journal, the latter data were included as they provided national, robust and objective measures of school-aged children's PA levels by province/territory throughout the time frame during which DPA policies were adopted and implemented. Thus, the final review included 13 articles describing 9 unique studies, and data from the Canadian Fitness and Lifestyle Research Institute. References within these papers to additional documents describing the history of DPA-related legislation within each province were followed up and added to timelines as appropriate.

\section{Data analyses}

\section{Characterization of adopters}

Rogers' Diffusion of Innovations framework categorizes adopters into 1 of 5 adopter categories (innovators, early adopters, early majority, late majority, laggards) based on the time at which they adopt a new idea, which defines their position within a typical S-shaped adoption curve [45]. Given the small number of provinces with DPA policies, an adoption curve could not be empirically fitted. In addition, there is no consensus as to whether adopters should be classified on the basis of when they decide to use, or actually begin using a new idea [45]. Because the number of adopters was small we were able to use a hybrid approach in which we classified adopters into categories based on their earliness in both adopting and implementing DPA policies relative to other provinces over the 7 year time frame during which adoption occurred (2003-2010) .

\section{Policy content}

DPA policy statements for each province were reviewed to identify major elements of each policy including: type of language used (e.g. prescriptive, specific), number of minutes of PA required and over what time frame (e.g. sustained, smaller time segments), types of PA required (e.g. MVPA), time of day during which PA had to be performed 
(e.g. instructional time, non-instructional time), grade-levels included, implementation timelines and enforcement mechanisms. Policy strength was evaluated using the method of Carlson et al. [50] by 2 independent reviewers. Weak policies were those that were vague and used non-specific language to provide suggestions or recommendations, rather than requirements. Moderately strong policies used specific language to mandate minimum PA time requirements and MVPA (as opposed to PA, which is vague and can include light intensity PA). Strong policies were required to meet the criteria for moderately strong policies and to include mechanisms for implementation and monitoring.

\section{Policy context}

Documents associated with all timeline events were rereviewed in detail and summarized in narrative format for each province, following a standard chronological outline that highlighted key contextual events. The study's second author, who had been responsible for developing the initial comprehensive timelines, reviewed the final timelines and narratives for accuracy and completeness.

\section{Policy evaluation}

Data from included studies were extracted by 2 independent investigators, who examined study objectives, design, sampling and measures, results and conclusions. Disagreements were resolved through discussion. Presentation of results was limited to DPA-specific findings, as other findings found within some papers (e.g. individual predictors of PA behaviors) were beyond the scope of the current review.

\section{Results}

\section{Characterization of adopters and policy content}

Five provinces of Canada's 13 provinces and territories (38.5\%) have province-wide DPA policies: British Columbia $(\mathrm{BC})$, Alberta $(\mathrm{AB})$, Saskatchewan (SK), Manitoba (MB) and Ontario (ON) (Figure 2), representing 72\% of Canadian children aged 5-19 years. Table 1 designates each province within an adopter category and summarizes the content and strength of each province's DPA policies. AB and ON were classified as innovators because they announced policies within a few years of each other (2003 and 2005, respectively) and implemented them in the same year (2005). $\mathrm{MB}$ and $\mathrm{BC}$ adopted and implemented policies virtually simultaneously (2007-08), but several years after AB and ON, marking them as early adopters. SK lagged behind the others by several years (2010), and was therefore classified as part of the early majority, although it is too early in the course of diffusion to know for certain whether this categorization is appropriate. If SK truly is part of the early majority, then diffusion should accelerate at some point in the near future. By contrast, if other provinces fail to adopt

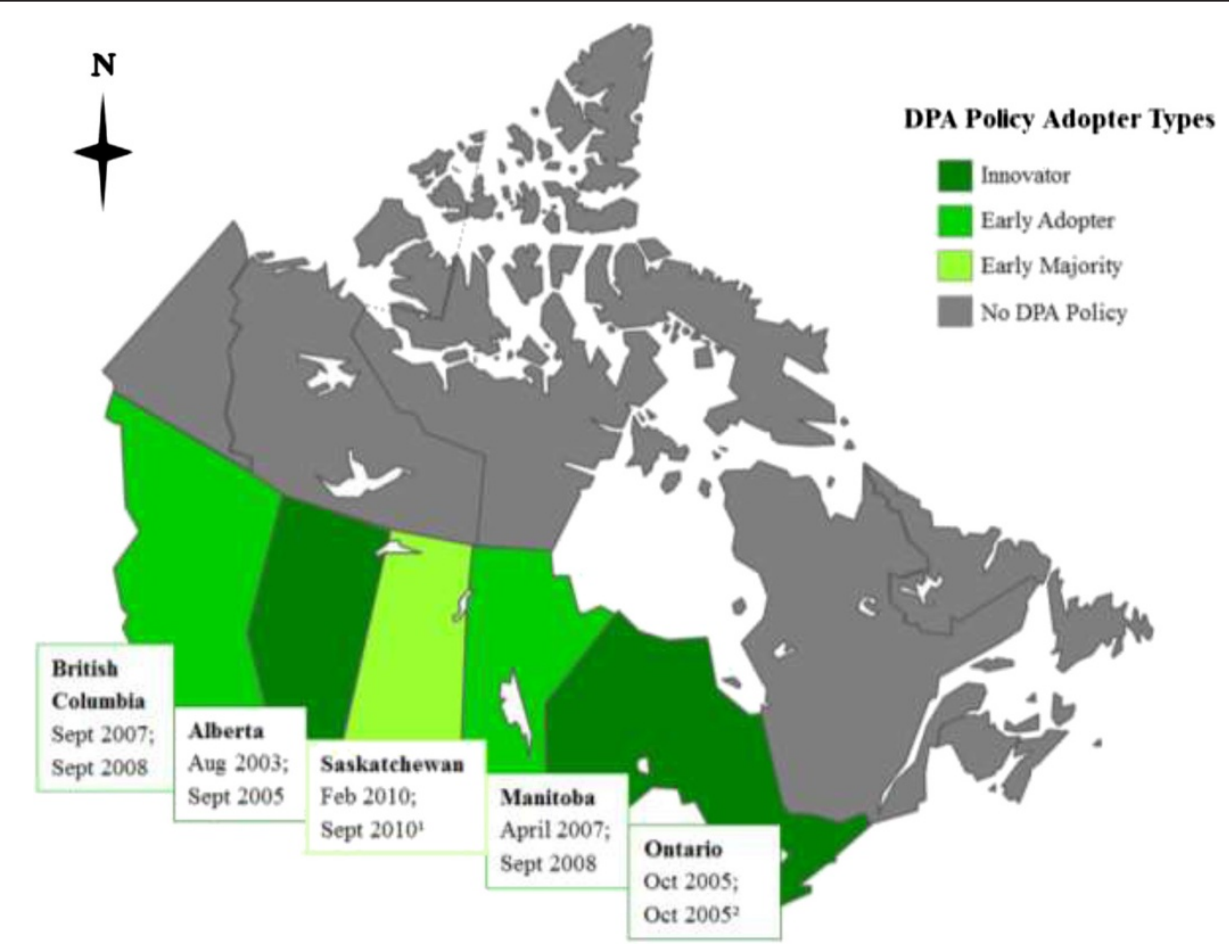

Figure 2 Map of time of adoption and implementation of Canadian daily physical activity policies. Provinces are listed in bold, followed by the date of DPA policy adoption and the date of DPA policy implementation. The date on which DPA policies were publicly announced was used as a proxy for the date of policy adoption. ' Optional implementation. ${ }^{2}$ Full implementation expected by the end of the 2005-06 school year. DPA: daily physical activity. 
Table 1 Summary of provincial daily physical activity policies

\begin{tabular}{|c|c|c|c|c|c|c|c|c|c|}
\hline Province & Grade & $\begin{array}{l}\text { Minutes and } \\
\text { distribution }\end{array}$ & Type of PA & Delivery of $\mathrm{PA}^{1}$ & Strength $^{2}$ & $\begin{array}{l}\text { Date } \\
\text { adopted }^{3}\end{array}$ & $\begin{array}{l}\text { Date } \\
\text { implemented }\end{array}$ & $\begin{array}{l}\text { Key adoption } \\
\text { factors }\end{array}$ & $\begin{array}{l}\text { Monitoring of } \\
\text { implementation } \\
\text { and impact }\end{array}$ \\
\hline \multicolumn{10}{|l|}{ Innovators 2003-2006 } \\
\hline AB $[56,66,158,159]$ & $\begin{array}{l}\text { Grades } \\
1-9\end{array}$ & $\begin{array}{l}\geq 30 \text { mins } / d \text {; } \\
\text { may be offered } \\
\text { in smaller time } \\
\text { segments }\end{array}$ & $\begin{array}{l}\text { PA should } \\
\text { vary in } \\
\text { form and } \\
\text { intensity }\end{array}$ & $\begin{array}{l}\text { Activities organized by } \\
\text { the school; can include } \\
\text { instructional or non- } \\
\text { instructional hours } \\
\text { (school-based) }\end{array}$ & Weak & Aug, 2003 & Sept, 2005 & $\begin{array}{l}\text { Convergence of Kingdon's } 3 \\
\text { policy streams: problem, } \\
\text { solution, and policy; strongly } \\
\text { influenced by the actions of } \\
\text { the Minister of Learning }\end{array}$ & $\begin{array}{l}\text { School authorities } \\
\text { responsible to monitor } \\
\text { implementation; DPA } \\
\text { survey of educators } \\
\text { conducted by AB } \\
\text { Education }\end{array}$ \\
\hline ON $[17,68,70,71]$ & $\begin{array}{l}\text { Grades } \\
1-8\end{array}$ & $\begin{array}{l}\geq 20 \text { mins/d; } \\
\text { sustained }\end{array}$ & $\begin{array}{l}\text { Sustained } \\
\text { MVPA }\end{array}$ & $\begin{array}{l}\text { During instructional } \\
\text { hours }\end{array}$ & Moderate & Oct, 2005 & $\begin{array}{l}\text { Oct, } 2005 \text {, with full } \\
\text { implementation by } \\
\text { end of 2005/06 } \\
\text { school year }\end{array}$ & $\begin{array}{l}\text { DPA in schools was part of } \\
\text { the } 1998 \text { Health and PE } \\
\text { curriculum, the Active } 2010 \\
\text { sport and PA strategy and } \\
\text { Living School, and was } \\
\text { supported by the Chief } \\
\text { Medical Officer of Health }\end{array}$ & $\begin{array}{l}\text { School Boards responsible } \\
\text { to monitor DPA } \\
\text { implementation }\end{array}$ \\
\hline \multicolumn{10}{|l|}{$\begin{array}{l}\text { Early adopters, } \\
2006-2010\end{array}$} \\
\hline MB $[75,79,80,160,161]$ & $\begin{array}{l}\text { Grades } \\
11-12\end{array}$ & $\begin{array}{l}1 \mathrm{PE} / \text { Health } \\
\text { Education } \\
\text { credit required } \\
\text { per grade } \\
\text { including PA } \\
\text { practicum of } \geq \\
55 \mathrm{hrs}\end{array}$ & $\begin{array}{l}\text { PA } \\
\text { practicum } \\
\text { focusses on } \\
\text { MVPA }+\geq 1 \\
\text { of: strength, } \\
\text { endurance, } \\
\text { flexibility }\end{array}$ & $\begin{array}{l}\text { In-, out- or a combination of } \\
\text { in- and out-of-class/school } \\
\text { time with adult sign off for } \\
\text { out-of-class/school PA }\end{array}$ & Moderate & Apr, 2007 & Sept, 2008 & $\begin{array}{l}\text { The Healthy Kids, Healthy } \\
\text { Futures Task Force Report } \\
\text { recommended mandating PE } \\
\text { for grades } 11-12\end{array}$ & $\begin{array}{l}\text { Students must complete } \\
\text { a personal fitness portfolio; } \\
\text { teachers document student- } \\
\text { level completion on report } \\
\text { cards }\end{array}$ \\
\hline \multirow[t]{3}{*}{$\begin{array}{l}\text { BC } \\
{[89,91,119,137,162,163]}\end{array}$} & $\begin{array}{l}\text { Kinder- } \\
\text { garten }\end{array}$ & $\begin{array}{l}15 \text { mins/d } \\
\text { (half-day) } 30 \\
\text { mins/d (full } \\
\text { day); may be } \\
\text { offered in } \\
\text { smaller time } \\
\text { segments of } \geq \\
10 \text { mins }\end{array}$ & $\begin{array}{l}\text { Includes } \\
\text { endurance, } \\
\text { strength } \\
\text { and/or } \\
\text { flexibility } \\
\text { activities }\end{array}$ & $\begin{array}{l}\text { Part of students' } \\
\text { educational program; can } \\
\text { include instructional or } \\
\text { non-instructional hours } \\
\text { (school-based) }\end{array}$ & Weak & Sept, 2007 & Sept, 2008 & $\begin{array}{l}\text { Action Schools! BC was an } \\
\text { early model of DPA that } \\
\text { proved efficacious and was } \\
\text { disseminated across BC }\end{array}$ & $\begin{array}{l}\text { School Boards develop } \\
\text { their own policies and } \\
\text { procedures to track DPA } \\
\text { implementation; teachers } \\
\text { document student-level } \\
\text { achievement on term } \\
\text { and final report cards }\end{array}$ \\
\hline & $\begin{array}{l}\text { Grades } \\
1-7\end{array}$ & $\begin{array}{l}30 \text { mins/d; may } \\
\text { be offered in } \\
\text { smaller time } \\
\text { segments of } \geq \\
10 \text { mins }\end{array}$ & $\begin{array}{l}\text { Includes } \\
\text { endurance, } \\
\text { strength } \\
\text { and/or } \\
\text { flexibility } \\
\text { activities }\end{array}$ & $\begin{array}{l}\text { Part of students' } \\
\text { educational program; can } \\
\text { include instructional or } \\
\text { non-instructional hours } \\
\text { (school-based) }\end{array}$ & Weak & Sept, 2007 & Sept, 2008 & $\begin{array}{l}\text { Action Schools! BC was an } \\
\text { early model of DPA that } \\
\text { proved efficacious and was } \\
\text { disseminated across BC }\end{array}$ & $\begin{array}{l}\text { School Boards develop } \\
\text { their own policies and } \\
\text { procedures to track } \\
\text { DPA implementation; } \\
\text { teachers document } \\
\text { student-level achievement } \\
\text { on term and final report } \\
\text { cards }\end{array}$ \\
\hline & $\begin{array}{l}\text { Grades } \\
8-9\end{array}$ & $\begin{array}{l}30 \text { mins/d; may } \\
\text { be offered in } \\
\text { smaller time } \\
\text { segments of } \geq \\
10 \text { mins OR } \\
150 \text { mins/wk }\end{array}$ & $\begin{array}{l}\text { Includes } \\
\text { endurance, } \\
\text { strength } \\
\text { and/or } \\
\text { flexibility } \\
\text { activities } \\
\text { OR MVPA }\end{array}$ & $\begin{array}{l}\text { Part of students' } \\
\text { educational program; can } \\
\text { include instructional or } \\
\text { non-instructional hours } \\
\text { (school-based) OR In- or } \\
\text { out- of school PA docu- } \\
\text { mented by student }\end{array}$ & Weak & Sept, 2007 & $\begin{array}{l}\text { Sept, 2008; as of } \\
\text { Sept, } 2011 \text { schools } \\
\text { select } 30 \text { mins/d } \\
\text { DPA OR } 150 \text { mins } \\
\text { MVPA/wk }\end{array}$ & $\begin{array}{l}\text { Action Schools! BC was an } \\
\text { early model of DPA that } \\
\text { proved efficacious and was } \\
\text { disseminated across BC }\end{array}$ & $\begin{array}{l}\text { School Boards develop their } \\
\text { own policies and procedures } \\
\text { to track DPA implementation; } \\
\text { teachers document student- } \\
\text { level achievement on term } \\
\text { and final report cards }\end{array}$ \\
\hline
\end{tabular}


Table 1 Summary of provincial daily physical activity policies (Continued)

Grades 150 mins/wk MVPA In-or out- of school PA

10-12 documented by student

Moderate Sept, 2007 Sept, 2008

Action Schools! BC was an early model of DPA tha proved efficacious and disseminated across BC

School Boards develop their own policies and procedures to track DPA implementation; teachers document student-lev achievement on term and final report cards; graduation requirement

\section{Early majority, 2010 - 2014}

\section{SK [100-103,105]}

All $30 \mathrm{mins} / \mathrm{d}$
students

MVPA

Not specified; School Boards expected to

develop new or

strengthen existing PA

policies consistent with

general government

Weak Feb, 2010 Sept, 2010

(optional)

The SK population health

strategy, SK in motion, and

School Boards responsible

to ensure that policy

implementation of Quality results in increased PA

Daily PE focused attention on for all children

the need for greater PA in

schools

$$
\text { guidelines }
$$

DPA: Daily physical activity; MVPA: moderate-to-vigorous physical activity; PA: physical activity; PE: physical education.

Instructional and in-class time both refer to teacher-initiated and supervised activities that take place in a formal classroom setting. Non-instructional and out-of-class time can include school and non-school-based activities [79].

${ }^{2}$ Policy strength was evaluated using the method of Carlson et al. [50] by 2 independent reviewers.

${ }^{3}$ The date on which DPA policies were publicly announced was used as a proxy for the date of policy adoption. 
policies in a timely manner, or at all (in which case the Sshaped curve may not apply), then SK may be better characterized as an early adopter, or alternatively as the final adopter.

Although the underlying objectives of the 5 policies are similar, namely to alter the school environment in order to increase children's PA levels and improve their health, there are clear differences among them. The $\mathrm{ON}$ policy, for instance, requires $\geq 20$ minutes of sustained daily MVPA, whereas others do not require sustained activity and $\mathrm{AB}$ does not require MVPA at all. $\mathrm{ON}$ is also distinct in requiring $\geq 20$ minutes of DPA, whereas all other provinces mandate $\geq 30$ minutes of PA daily or $\geq 150$ minutes weekly. The requirement for DPA within MB's new PE/Health Education curriculum applies exclusively to students in grades $11-12$, whereas the $\mathrm{AB}$ and $\mathrm{ON}$ policies apply only to younger students (grades 1-9 and 1-8, respectively). BC and SK are the only provinces with DPA policies that apply to students in all grades. The policies also differ as to when DPA must be provided. In ON, DPA must be delivered during instructional time, whereas $\mathrm{AB}$ allows DPA to be provided at any point during the school day. Provinces that mandate DPA in higher grades permit some or all PA to be achieved outside of school hours, with documentation by students or responsible adults. All policies allow PE time to be used to meet policy objectives. The SK policy is distinct in that it contains few specific provisions and its implementation was characterized as optional during discussions (Government of Saskatchewan, personal communication, September 4, 2014).

\section{Policy context}

Table 2 summarizes key contextual events preceding adoption and implementation of DPA policies in each province.

\section{Innovators, 2003-2006}

Emergence of DPA policies in AB Established in 1962, the Health and Physical Education Council of the $A B$ Teachers' Association provided early leadership for increased provision of PE/PA within schools [51]. In 1984, the Council released 2 position papers calling for $30 \mathrm{mi}-$ nutes of Quality Daily PE in AB schools [18,52], while in 1989 it developed Schools Come Alive, a pilot project to increase students' awareness and skills for active living [9]. The program was subsequently expanded to a provincial level and aimed to integrate active living initiatives within $\mathrm{AB}$ schools [53]. Among the program's most notable initiatives were a 1995 strategic plan for prioritizing school-based PA and PE, and creation of Ever Active Schools in 2001, which later became an important provider of DPA-related resources [53]. The AB Coalition for Healthy School Communities, a network of individuals and organizations committed to school heath, was another early player in efforts to embed health promotion within $\mathrm{AB}$ schools [54].

Although these early initiatives were important, according to a retrospective qualitative analysis of the adoption of DPA policies in AB, DPA was specifically mandated in Alberta schools because in 2003 the 3 streams within Kingdon's streams model [55] (i.e. problem, solution and politics) converged [56]. First, a number of high profile reports focused attention on the contribution of inadequate PA to childhood obesity and poor health outcomes (i.e. problem stream) [57-59]. Second, school-based DPA was acknowledged in a number of influential venues as a potentially viable and effective means to increase children's PA levels (i.e. solution stream) [18,60-63]. AB's 1998 Active Living Strategy was among these reports which recommended that schools create opportunities for students to be physically active each school day [63]. The emphasis on PA and attainment of life-long active living within AB's PE curriculum at the time $[62,64]$ and creation of Ever Active Schools [53] also helped to build momentum for, and establish a supportive context for school-based DPA. In 2003, Kingdon's 3 streams were linked when the Minister of Learning used his ministerial power to propose a DPA policy as a viable political solution to the problems of inactivity and obesity among children (i.e. politics stream) [56]. Although initially announced as a daily PE policy for grades 1-12 [65] this error by the Minister was quickly corrected and a DPA policy was implemented in September, 2005 in grades 1-9 [66]. Plans to implement DPA in high schools in September, 2006 were cancelled, reportedly due to stakeholder concerns [67].

Emergence of DPA policies in ON In October, 2005, ON became the second Canadian jurisdiction to announce a DPA policy for schools [68], although as early as 1998 the ON Health and PE curriculum required student participation in daily, sustained, moderate or vigorous PA (with time expectations for some grades) [17]. The new policy, which was to be implemented by the end of the 2005-06 school year [68], was occasioned by the confluence of 3 high-profile reports. First, in response to development of a Canadian Sport Policy in 2000-01, ON developed a Sport Action Plan Framework and subsequently a full ACTIVE2010 Sport and Physical Activity Strategy in 2004 [69]. The strategy represented a critical juncture, as in it the Ministry of Health Promotion highlighted the importance of policy in creating change and pledged to support implementation of 20 minutes of DPA in elementary schools [69]. The strategy also led to development of the ON Healthy Schools Program in 2004, of which DPA policies were to become a part [70,71].

Also in 2004, the ON Chief Medical Officer of Health released a report entitled "Healthy Weights, Healthy 
Table 2 Policy timelines by province

\begin{tabular}{ll}
\hline Date & Event \\
[reference] & \\
\hline
\end{tabular}

\begin{tabular}{ll}
\hline Alberta & \\
$1984[18,52]$ & The Health and Physical Education Council of the AB Teachers' Association releases 2 position \\
& papers calling for 30 minutes of Quality Daily PE in AB schools. \\
& The Health and Physical Education Council of the AB Teachers' Association develops Schools \\
& Come Alive to increase students' awareness and skills for active living. \\
& The AB Coalition for Healthy School Communities is created to facilitate networking and \\
$1990[54]$ & information sharing among those with an interest in comprehensive school health. \\
$1995[53]$ & Schools Come Alive releases a strategic plan to make PA and PE priorities in AB schools. \\
$1998[63]$ & AB's Active Living Strategy recommends that AB schools create opportunities for students to \\
$2000[64]$ & be physically active each school day. \\
$2001[53]$ & AB releases a new PE curriculum emphasizing PA and attainment of life-long active living. \\
$2001[57]$ & Schools Come Alive creates Ever Active Schools as a pilot project to encourage active living \\
& initiatives in schools. \\
& The Coalition for Active Living reports PA has declined in Canada partly because PE has been \\
& cut in schools. \\
& The Mazankowski report suggests students should have the opportunity for regular exercise as \\
& part of every school day. \\
$2002[60]$ & Delegates at the AB Future Summit propose re-introducing daily PA into the school curriculum. \\
$2003[62]$ & AB's Commission on Learning recommends a new wellness program for students from \\
$2003[56,65]$ & kindergarten to grade 12 that includes some form of daily activity. \\
$2005[66,67]$ & AB Learning announces a daily PE policy for students in grades 1-12 (later corrected to DPA). \\
& AB implements a DPA policy for grades 1-9. Plans to implement DPA in high schools are cancelled. \\
&
\end{tabular}

\section{Ontario}

1998 [17]

ON releases a Health and PE curriculum requiring student participation in daily, sustained, moderate or vigorous PA (with minimum time expectations for some grades).

ON develops a Stakeholder Sport Action Plan to support the Canadian Sport Policy'.

The Ministry of Health and Long-Term Care proposes a school-based, province-wide initiative for primary prevention of diabetes.

ON implements a Healthy Schools Program.

A comprehensive school health initiative called Living School is launched, and includes DPA.

The Chief Medical Officer of Health releases a report recommending policies be developed to support the ACTIVE2010 Sport and Physical Activity Strategy, and that quality daily PE and PA opportunities be provided in schools.

2004 [69]

$2005[68]$

ON's ACTIVE2010 Sport and Physical Activity Strategy supports implementation of 20 minutes of DPA in elementary schools.

2006 [68]

ON announces a DPA policy for grades 1-8.

\section{British Columbia}

1983 [86]

1989 [86]

1992 [86]

2002 [86]

2001-02 [88,89]

$2003[86,87]$

The Directorate of Agencies for School Health (DASH) BC is established and later introduces the concept of comprehensive school health in $B C$ schools.

A Government Office of Health Promotion is established in BC.

A Healthy Schools program is launched throughout BC.

The Healthy Schools program ends.

Stakeholder consultations to identify the strategic agenda for action on PA in BC schools leads to development of Action Schools! BC.

The BC Provincial Health Officer's report recommends a re-commitment to support Healthy Schools initiatives.

Action Schools! BC is evaluated and proves acceptable, feasible and efficacious. 
Table 2 Policy timelines by province (Continued)

\begin{tabular}{|c|c|}
\hline 2003-04 [93] & BC develops a chronic disease prevention strategy, Healthy BC 2010. \\
\hline $2004[92]$ & Widespread dissemination of Action Schools! BC is funded through the Healthy Schools Program. \\
\hline $2005[93,94]$ & $\begin{array}{l}\text { The BC Healthy Living Alliance circulates The Winning Legacy to each Ministry to advocate } \\
\text { for multi-level interventions (including school-based initiatives) to curb chronic disease. }\end{array}$ \\
\hline $2005[93]$ & $\begin{array}{l}\text { Healthy BC } 2010 \text { is renamed ActNowBC and aims to make BC a North American leader in healthy } \\
\text { living and physical fitness. }\end{array}$ \\
\hline $2006[95]$ & $\begin{array}{l}\text { The BC Medical Association recommends } 30 \text { minutes of DPA in schools to the BC Select Standing } \\
\text { Committee on Health. }\end{array}$ \\
\hline $2006[96]$ & $\begin{array}{l}\text { The Select Standing Committee on Health recommends that every student be required } \\
\text { to participate in DPA and that Action Schools! BC be expanded. }\end{array}$ \\
\hline $2007[97]$ & $\begin{array}{l}\text { The BC government announces that DPA will be mandated in all BC schools (kindergarten } \\
\text { to grade 12). }\end{array}$ \\
\hline 2008 [97] & A DPA policy is implemented in all BC schools. \\
\hline \multicolumn{2}{|l|}{ Manitoba } \\
\hline $1975[74]$ & $\begin{array}{l}\text { A MB Physical Education Working Group proposes that all MB schools be required to offer } \\
40 \text { minutes of PE per day, including } 20 \text { minutes of vigorous PA. }\end{array}$ \\
\hline $2000[75]$ & $\begin{array}{l}\text { MB adopts an integrated approach to PE/Health Education programming that recognizes the } \\
\text { value of regular PA. }\end{array}$ \\
\hline $2000[76]$ & The Healthy Child MB Strategy is implemented that focusses on creating child-centered public policy. \\
\hline $2000[77]$ & Nurses-in-Schools is introduced to support public health in schools. \\
\hline $2002[78]$ & The MB Physical Activity Action Plan recommends mandating daily PE from kindergarten to grade 12. \\
\hline $2003[77]$ & $\begin{array}{l}\text { Nurses-in-Schools expands to become MB Healthy Schools, a program that draws on the principles of } \\
\text { comprehensive school health. }\end{array}$ \\
\hline $2005[80]$ & $\begin{array}{l}\text { The Healthy Kids, Healthy Futures Task Force Report recommends changes to the MB PE/Health } \\
\text { Education curriculum and a voluntary in motion program to engage students in } 30 \text { minutes of DPA. }\end{array}$ \\
\hline $2005[79]$ & The MB government pledges to implement all 47 of the Task Force's recommendations. \\
\hline $2005[82,83]$ & $\mathrm{MB}$ in motion is launched to increase PA in MB. \\
\hline $2005[84]$ & $\begin{array}{l}\text { Healthy Schools and MB in motion partner to offer Healthy Schools in motion to support } 30 \text { minutes } \\
\text { of DPA for all students. }\end{array}$ \\
\hline $2007[79,85]$ & $\begin{array}{l}\text { The MB government mandates the amount of time students in kindergarten to grade } 10 \text { must spend } \\
\text { in PE/Health Education classes. }\end{array}$ \\
\hline $2008[79]$ & $\begin{array}{l}\text { The MB government implements a PE/Health Education curriculum for students in grades } 11-12 \text {. } \\
\text { Students in grades } 11-12 \text { are required to complete } 2 \text { PE/Health Education credits for graduation, } \\
\text { including } \geq 55 \text { hours of MVPA per credit. }\end{array}$ \\
\hline \multicolumn{2}{|l|}{ Saskatchewan } \\
\hline $2001[98]$ & School ${ }^{\text {PLUS }}$ is released, outlining a vision for schools to meet the needs of the 'whole' child. \\
\hline $2001[99]$ & $\begin{array}{l}\text { In response to the Clear Lake Accord', SK releases a provincial strategy with a goal of ensuring } \\
\text { schools provide DPA called A Physically Active SK. }\end{array}$ \\
\hline $2003[101]$ & SK in motion is launched to increase PA across the province. \\
\hline $2004[100]$ & The SK population health strategy outlines a plan to support regular PA in schools. \\
\hline $2006[101,102]$ & $\begin{array}{l}\text { SK in motion changes its focus to school-aged children and promotes } 30 \text { minutes of PA at } \\
\text { home, } 30 \text { minutes at school and } 30 \text { minutes in the community. In motion schools provide } \geq 30 \\
\text { minutes of DPA. }\end{array}$ \\
\hline $2009[103,104]$ & Quality Daily PE is reported to be widely implemented in SK. \\
\hline $2010[105]$ & A provincial DPA policy is announced for all schools. \\
\hline 2010 & Voluntary ${ }^{2}$ implementation of the DPA policy begins. \\
\hline
\end{tabular}

DPA: Daily physical activity; MVPA: moderate-to-vigorous physical activity; PA: physical activity; PE: physical education.

${ }^{1}$ Provincial response to a federal policy.

${ }^{2}$ Government of Saskatchewan, personal communication, September 4, 2014. 
Lives" that recommended policies be developed to support the ACTIVE2010 Sport and Physical Activity Strategy, and that quality daily PE and PA opportunities be provided in ON schools [72]. Finally, in response to a 2002 report by the Ministry of Health and Long-Term Care, funding was allocated to develop a provincial school-based initiative for diabetes prevention, which became known as Living School [73]. Based upon the tenets of comprehensive school health (synonymous with Health Promoting Schools in Europe and Coordinated School Health in the US), the program involved implementation of DPA, and provided an early model of the potential of DPA to increase children's PA levels [73].

\section{Early adopters, 2006-2010}

Emergence of DPA policies in MB In 1975, a MB Physical Education Working Group proposed that all $\mathrm{MB}$ schools be required to offer an average of 40 minutes of PE per day, including 20 minutes of vigorous PA [74]. Subsequent to this early recommendation, the genesis of MB's DPA-related policies appears to have been in the year 2000, through several key activities. First, that year $\mathrm{MB}$ adopted an integrated approach to PE/Health Education programming [75]. A key principle was that students should be physically active on a regular basis as part of the learning process [75]. Also in 2000, the government of $\mathrm{MB}$ implemented the Healthy Child $\mathrm{MB}$ Strategy that focused on creating child-centered public policy [76]. That same year, "Nurses-in-Schools" was introduced to support public health in schools [77], and, following a provincial consultation in 2002, expanded to become Healthy Schools, a program that draws on the principles of comprehensive school health [77]. Another key event in 2000-02 was the development of the MB Physical Activity Action Plan which recommended mandating daily PE from kindergarten to grade 12 [78].

Although these early activities built momentum for PA/ PE promotion in MB schools, the precipitating event for the emergence of DPA policies in MB occurred in 2005, with the release of the Healthy Kids, Healthy Futures Task Force Report [79]. Announced in August, 2004, the Task Force heard testimony recommending that PE be mandated from kindergarten to grade 12, while others supported provision of DPA [80,81]. In its final report, the committee recommended that the government mandate the amount of time students in kindergarten to grade 10 spent in $\mathrm{PE} /$ Health Education classes, develop a PE/Health Education curriculum for grades 11 and 12, and require students in grades 11 and 12 to take 2 semesters of the course for graduation [80]. The Task Force also recommended that the provincial government introduce a voluntary $\mathrm{MB}$ in motion program in which students from in motion schools must participate in 30 minutes of DPA [80].
The MB government pledged to implement all 47 of the Task Force's recommendations [79], and shortly thereafter launched $\mathrm{MB}$ in motion to increase PA in MB by $10 \%$ by $2010[82,83]$. Healthy Schools and MB in motion subsequently partnered to offer Healthy Schools in motion. In motion schools commit to working towards the goal of providing 30 minutes of DPA for all students through any combination of PE, PA breaks and programs, intramurals and special events [84]. The other $\mathrm{PE} /$ Health Education-related Task Force recommendations were fulfilled in 2007-08, including requiring students in grades 11 and 12 to complete $2 \mathrm{PE} /$ Health Education credits for graduation, and although it was not a Task Force recommendation, students in grades 11 and 12 were additionally required to participate in 55 hours of MVPA per PE/Health Education course $[79,85]$. Because only the grade 11-12 PE/Health Education curricula requires participation in a minimum amount of PA, it alone was considered a DPA policy for the purposes of the current analysis.

Emergence of DPA policies in BC Established in 1983 by the BC Ministries of Education and Health in partnership with community agencies, the Directorate of Agencies for School Health BC first introduced the concept of comprehensive school health in BC schools [86]. Later, a government Office of Health Promotion was established, launching a Healthy Schools program throughout the province in 1992 [86]. Although widely disseminated, the program was subsequently ended in 2002 [86]. In 2003, the comprehensive school health movement regained momentum following release of the Provincial Health Officer's Report which recommended a re-commitment to support Healthy Schools initiatives $[86,87]$.

It was in this context that in 2001-02, the BC ministries of Health and Tourism, Sport and the Arts initiated stakeholder consultations to identify the strategic agenda for action on PA in BC, with a focus on schools [88]. A proposal to mandate daily PE from kindergarten to grade 12 was opposed by education stakeholders, and instead, a flexible 'active school' model for PA promotion in elementary schools emerged [88,89]. The program, known as Action Schools! $\mathrm{BC}$, provided children with small PA breaks throughout the school day (in addition to scheduled PE classes), with the goal of providing 150 minutes/week of moderate intensity PA [89]. A 2003-04 evaluation supported the program's acceptability, feasibility and efficacy in increasing children's opportunities to be physically active, PA participation, and in improving their fitness and health-related outcomes [89-91]. Therefore, widespread dissemination of Action Schools! BC was funded through the Healthy Schools Program [92].

The impact of Action Schools! BC was widespread in terms of enhancing political support for promoting schoolbased PA in BC [88]. Similarly, the Healthy Schools Program 
helped to embed school health as a core element within the business plans of key government ministries [92]. The province's 2003-04 chronic disease prevention strategy, Healthy BC 2010, later renamed ActNowBC, was also influential, as its focus on making $\mathrm{BC}$ a North American leader in healthy living and physical fitness helped to create a climate in which PA was supported and promoted across multiple government departments and societal sectors [93]. Advocacy by the BC Healthy Living Alliance for multi-level interventions (including school-based actions) to address chronic disease was also influential in this respect [93,94]. Ultimately, these capacity building and awareness raising activities culminated in a recommendation by the $\mathrm{BC}$ Medical Association to BC's Select Standing Committee on Health to implement 30 minutes of DPA in schools [95], and a subsequent strong endorsement by the committee that every student in BC's educational system be required to participate in DPA, and that Action Schools! BC be expanded even further [96]. In 2007, the BC government announced that DPA would be mandated in all BC schools in the 2008 school year, as a complement to, rather than a replacement for Actions Schools! BC [97].

\section{Early majority, 2010-2014}

Emergence of DPA policies in SK Discussion of the role of schools in society and in meeting the holistic needs of children surfaced in a number of forums in SK in the 1990's [98]. In response, a Task Force was formed that in 2001, produced a report outlining a vision to expand the role of schools beyond education to meet the needs of the 'whole' child which became known as School $^{\text {PLUS }}$ [98]. That same year, the SK government released 'A Physically Active SK' provincial strategy, with a goal of ensuring schools involved students in DPA [99]. The strategy represented the fulfillment of SK's pledge, along with the other federal-provincial/territorial ministers responsible for fitness, active living, recreation and sport to reduce physical inactivity among Canadians by $10 \%$ by 2003 [99]. As a complement to this strategy, a SK population health strategy was developed in 2004, outlining a government plan to support PA through increasing opportunities for, and reducing barriers to regular PA in schools [100]. Suggested actions included promoting PA policies in school divisions [100].

In 2003, SK in motion was launched to increase PA across the province, but in 2006 switched focus to school-aged children and youth, with a goal to 'get kids moving' through 30 minutes of PA at home, 30 minutes at school, and 30 minutes in the community [101]. In motion schools commit to providing $\geq 30$ minutes of DPA for all students [102]. SK in motion, along with Quality Daily PE [103] were widely implemented across the province [104] prior to the announcement of a provincial DPA policy in 2010 [105]. School divisions began optional implementation of DPA in September, 2010 (Government of Saskatchewan, personal communication, September 4, 2014).

\section{Non-adopters}

Quebec, the Atlantic provinces (Nova Scotia, New Brunswick, Prince Edward Island, Newfoundland and Labrador), and the northern territories (Northwest Territories, Yukon, Nunavut) Non-adopters consist of provinces/territories that have not yet adopted a DPA policy, although some may never adopt a policy. Currently, non-adopters are co-located geographically in Canada's eastern provinces and northern territories, and with the exception of Quebec, are among the least affluent and least populous regions of the nation [106,107]. Notably, however, 6 of these 8 provinces/territories have comprehensive school health initiatives in place or underway, which suggests that attention to school environments is a priority [108]. Action to address PA in schools is also evident in all of these jurisdictions. For example, in 2006 a bill in New Brunswick proposed mandating 150 minutes/ week of PA for all students [109], while in Nova Scotia, a 2007 bill proposed that students in grades 1-9 receive at least 30 minutes of DPA [110]. Neither of these bills was passed. Quebec en Forme is an example of another major provincial initiative aimed at increasing PA levels among children and youth [111].

\section{Canada}

Although we focused on describing provincial-level policy influences, at least two developments at the national level have been foundational for development of DPA policies in Canada, and are therefore briefly mentioned here. In 1974, the School Physical Activity Program Special Interest Group introduced the concept of Quality Daily PE within Canada [15], and in 1983, a proposal for a Quality Daily PE program emerged [15,112]. Officially launched in 1988, the program provides minimum standards for PE programs, including $\geq$ 30 minutes of daily PE with a high degree of student participation [112]. The Quality Daily PE concept, including provision of DPA, was immediately and strongly endorsed by the federal Minister of State, Fitness and Amateur Sport at the time [15]. Formation of the Pan-Canadian Joint Consortium for School Health in 2005 marked another key turning point for school health in Canada [113]. A partnership of federal, provincial, and territorial governments, the Consortium aims to build capacity to promote school health and to act as a catalyst for collaborative activities and actions [113]. Importantly, the Consortium has provided a venue to share information regarding DPA policies and programs across Canada [92]. 


\section{Policy evaluation: Findings from the systematic review Adoption and diffusion}

One study examined adoption of DPA policies in $A B$ (Table 3). No studies examined diffusion of DPA policies.

\section{Implementation}

A total of 8 papers (6 studies) evaluated DPA policy implementation in $\mathrm{ON}$ and $\mathrm{BC}$, including adherence to DPA policies, implementation models, processes and perspectives of implementation (Table 3). All of the studies were cross-sectional, although 1 used a pre-post comparison design. One study reported findings from a document review, another conducted key informant interviews, while the remainder used self-report methods (surveys and teacher logs) to assess implementation-related outcomes. None of the studies included control groups. Their collective results suggest moderate, but inconsistent implementation of DPA policies, however findings are tentative as there was significant variability in the methods used, and in the outcomes considered across studies. Moreover, there were very few studies, and samples sizes were small in all but 1 study. Process evaluations showed that an important barrier to implementing DPA policies was a lack of time to provide additional PA given competing curricular demands and priorities.

\section{Impact}

Impact of the $\mathrm{ON}, \mathrm{MB}$ and $\mathrm{BC} \mathrm{DPA}$ policies was assessed in 9 papers ( 5 studies) (Table 3 ). Seven papers were based on cross-sectional assessments, 1 used a pre-post comparison design, and 1 followed students longitudinally for up to 4 years. Three papers used accelerometry, while the remainder relied on selfreported surveys to assess PE delivery, PA behaviors, and BMI. While the number of students included in each study was large, the number of schools was small in all but 1 study, and none of the studies included control groups of students who were not exposed to DPA policies (i.e. from other jurisdictions). In addition, the Canadian Fitness and Lifestyle Research Institute used pedometers to quantify the number of steps taken daily by school-aged children on a national level $[114,115]$. Findings showed that with the exception of SK, in which a decline was observed, the average number of daily steps taken by school-aged children in provinces with DPA policies did not change between 2005 and 2011, and none differed from the national average (Table 4). Taken together, the available data suggest that Canadian DPA policies have had little to no impact on schoolaged children's PA levels or BMI; however findings are tentative in light of variability in methods used, outcomes considered, and the small number of studies.

\section{Discussion}

Canada has enacted relatively little legislation designed to increase population-level PA. DPA policies represent an innovative approach to increase children's PA in schools because they are intended to extend beyond PE classes to promote PA throughout the school day. Between 2003 and 2014, 5 of Canada's 13 provinces and territories adopted school-based DPA policies, however our analysis suggests the strength of these policies was low to moderate. To explore factors associated with policy adoption and diffusion, in the following sections we compare and contrast the characteristics of adopters, the nature of their DPA policies, and the context surrounding DPA policy adoption. We conclude by discussing evidence regarding the level of implementation and impact of Canadian DPA policies.

\section{Policy content}

Schools face many barriers to implementing DPA, and therefore the motivation to implement DPA may in some cases relate to the strength of accountability mechanisms in place to monitor implementation [116]. For this reason, provisions for monitoring and enforcement were used to distinguish strong from moderately strong policies [50]. None of the DPA policies met the benchmark for a strong policy, although policies in $\mathrm{ON}, \mathrm{BC}$ (grades 10-12) and MB were rated as moderately strong. ON's 2005 policy was the most prescriptive and specific, and might therefore be considered the strongest according to the criteria used. Policies in $\mathrm{AB}$ and $\mathrm{BC}$ (kindergarten to grade 9) were weak because they did not specify that PA should be performed at a moderate-to-vigorous intensity. The 2010 SK policy was perhaps the weakest of the 5 , as it used non-specific language and gave School Boards the responsibility to develop their own DPA policies consistent with certain minimum standards. Moreover, although not described as optional within government policy documents, the policy was characterized as optional during discussion with government officials (Government of Saskatchewan, personal communication, September 4, 2014). It is therefore apparent that diffusion of Canadian DPA policies did not lead to a strengthening of policy over time. By comparison, among 14 US states with school-based DPA policies, 10 policies were weak, 4 were moderately strong, and none were rated as strong, using the same criteria [50]. Stronger state-level PE laws have been associated with stronger district-level PE policies [40], greater PE time allotments in schools [26], as well as increased PE attendance and PA among children [28], suggesting that strengthening the provisions of DPA policies, particularly provisions for monitoring and enforcement, is an important priority for policy makers.

Flexible delivery models are a hallmark of Canadian DPA policies, such that individual schools, teachers and 
Table 3 Summary of study findings

\begin{tabular}{ll}
\hline Study & $\begin{array}{l}\text { Type of } \\
\text { evaluation }\end{array}$ \\
\hline
\end{tabular}

Study

Time frame

Population and setting Measures

Outcome variables

Results

Alberta

design

Noted

20 purposively selected

Semi-structured interviews key informants involved in school-based PA policy
processes; review of policy

documents and websites.

Policy processes that resulted in adding DPA but not active

transportation initiatives to the school curriculum

DPA succeeded because Kingdon's 3 streams

(problem, solution, politics) converged, largely through the actions of the Minister of Learning who used his ministerial power to link the solution with the

\section{ONTARIO}

1) Faulkner et al., 2014 Implementation Cross[133]; 2) Stone et al., and impact section

Apr-Jun, 2010; Sept-Dec, 865 grade 5-6 students 2010; Apr-Jun, 2011 from 18 elementary schools in Toronto, ON. participate, 18 schools selected from among interested schools based interested schools based upon neighborhood typ and SES,

ide

Students completed a survey, wore

accelerometers for 7 days and had height and

weight measured. Parents completed a survey and travel diary for their children. Principals completed a school health environment survey. Teachers provided classroom schedules to identify DPA and PE times.

\begin{tabular}{|c|c|c|c|c|}
\hline $\begin{array}{l}\text { 1) Leatherdale et al., } \\
2013[145] ; 2) \\
\text { Leatherdale et al., } \\
2014 \text { [147] }\end{array}$ & Impact & $\begin{array}{l}\text { Cross- } \\
\text { sectional }\end{array}$ & $2007-08$ & $\begin{array}{l}\text { Convenience sample of } \\
2326 \text { grade } 1-4 \text { students/ } \\
\text { parents from } 30 \\
\text { elementary schools in ON. } \\
\text { Schools were purposively } \\
\text { selected within public and } \\
\text { separate school boards }\end{array}$ \\
\hline
\end{tabular}

Students/parents completed a survey and students' height and weight were measured. Administrators completed a school health environment survey. political stream.
1) Time spent in light-tovigorous PA. Whether schools were in the initiation, action or maintenance stage of DPA. 2) Total PA counts and MVPA mins on school days and during school hours.

(n)

1) $11.1 \%$ of schools were in the initiation phase of DPA, 88.9\% were in the action phase and none were in the maintenance phase Students were not more physically active in schools that were in the action phase. 2) $49 \%$ of students were provided DPA every school day. Frequency of DPA positively associated with total PA and MVPA mins/d on weekdays and during the school day. Students who participated in DPA 5 d/wk had higher total counts and intensity of PA, and time spent in MVPA on school days and during the school day. PA bouts averaged 7.1 mins and none were $\geq 20$ mins Those who accumulated $\geq 1$ bout of MVPA were $\geq 1$ bout of MVPA were
more active and fewer were more active and fewer w

Student activity levels 1 1) DPA implementation (low, moderate, high) and was not associated with BMI (normal, overweight, the odds of being obese). Whether schools overweight or obese. 2) were in the initiation, DPA implementation was action or maintenance not associated with the stage of DPA. odds of being highly or moderately active.

$$
\text { moder }
$$




$\begin{array}{lll}\text { 1) Leatherdale et al., } & \text { Implementation } & \begin{array}{l}\text { Cross- } \\ \text { 2010 [134]; 2) Hobin }\end{array} \\ \text { et al., 2010 [146]; 3) } & \text { and impact } & \text { sectional } \\ \end{array}$

Leatherdale, 2010 [165]

Patton, 2012

Implementation Cross-

$$
\text { sectional }
$$

Not stated

\title{
Robertson-Wilson and
}

Implementation Qualitative

\begin{abstract}
Levesque, 2009 [166]
\end{abstract}
2005-07

and other documents
related to DPA

related to DPA

implementation.
Students completed a survey. Administrators completed a school

2379 (studies (study 3) grade 5-8 students from 30 schools health environment in ON. Schools were survey. public and separate school boards located in major geographic regions.

145 teachers within 37 randomly selected schools in the Thames Valley

District School Board, ON.

\section{Teachers completed a}$$
\text { District School Board, ON. }
$$

Whether DPA

implementation strategies fit Hogwood and Gunn's

10 preconditions for perfect implementation.
Student activity levels 1 1) 0\% of schools were in (ow, moderate, high) and the initiation phase of (normal, overweight, DPA, 80\% were in the obese). Whether schools action phase and 20\% action or maintenance phase Implem no associance stage of DPA. DPA DPA was not associated implementation models. with the odds of being moderately or highly active. 2) DPA

implementation models were: 70\% offered DPA only on days without PE class, $20 \%$ offered DPA class, $20 \%$ offered DPA in addition to daily PE class, $10 \%$ offered DPA as part of daily PE class. DPA implementation models were not associated with the odds of being moderately or highly active. 3) DPA implementation was not associated with the odds of being overweight.

15.6\% always conducted DPA on days when PE was not scheduled, $50.7 \%$ said there was not adequate time to conduct DPA, $60.9 \%$ said DPA should be integrated within the curriculum, $64.6 \%$ reported that administrators rarely or never monitored DPA. Several preconditions (e.g. allocation of resources, task specification) have been considered, whereas others considered, whereas oth (e.g. sustainability of resources, evaluation plans, extent to which policy is valued) require additional attention to ensure optimal DPA implementation.
Mins and delivery format Implementation of DPA of PE, stakeholder support policies was $65 \%, 56 \%$ and

\section{British Columbia}

Watts et al., 2014 [137]
Implementation Crossand impact sectional,
2007-08 and 2011-12 school years
Administrator surveys in all districts that consented.
Administrators completed a survey on PA practices 
Table 3 Summary of study findings (Continued) and 118 middle/high at their school for grades schools; 2011-12: 35 elementary and 125

middle/high schools. and level of

implementation of DPA

policies.

Semi-structured

Principals and teacher/

school informants $(n=50)$

from a variety of school

types and settings $(n=17$

schools.
Semi-structur
Factors that impeded or of DPA policies. facilitated implementation

$51 \%$ for grades 6,8 and 10 . Schools had higher odds of providing $\geq 150$ mins PE/wk and provided more mins of PE to grade 8 and 10 students in 2011-12.

Schools had higher odds of providing PA linearly to grade 8 and in a semester format to grade 10 students in 2011-12. Staff and parental support for PA policies increased in all schools, student support declined in elementary and increased in middle/ high schools, principal support was unchanged.

Perceived implementation ranged from $14 \%-90 \%$ Schools implemented DPA policies through prescriptive and nonprescriptive approaches. DPA policies provided an advantage relative to the status quo, were compatible with sehool philosi phies, and provided observable benefits. It was difficult to understand DPA policies, to fit them into already full schedules and policies increased teacher workload. Availability of resources and support were key facilitators.

\section{Manitoba}

Hobin et al., 2014 [148] Impact
Longitudinal Baseline measures were Convenience sample of conducted in 2008 with 2011 or completion of grade 12 annual follow-up to grades 9-10 PE classes within 31 randomly

selected secondary schools ( $n=447$ students) across
Students completed a survey at baseline and wore accelerometers for 7

days once a year.

MPA mins/d overall, and in rural/urban and low/ high SES areas.
The MVPA trajectories of adolescents declined $11.3 \% / y$ r from baseline to the last measurement Students with low or moderate baseline MVPA and those attending schools in low SES and rural areas had slower rates of decline in MVPA. 
Table 4 Summary of findings from the Canadian Fitness and Lifestyle Research Institute's Canadian Physical Activity Levels Among Youth (CANPLAY) studies [114]

\begin{tabular}{|c|c|c|c|c|c|}
\hline Province & Year & DPA policy? & $\begin{array}{l}\text { Approximate mean } \\
\text { \# steps taken }\end{array}$ & $\begin{array}{l}\text { Comparison with other } \\
\text { provinces/territories }\end{array}$ & $\begin{array}{l}\text { Change compared to } \\
2005-07 \text { and 2007-09 }\end{array}$ \\
\hline$\overline{N U^{1}}$ & $2009-11$ & No & $>13,000$ & Not reported & Not reported \\
\hline YK & 2009-11 & No & $12,300^{2}$ & More steps than NF, NS, NB & No change \\
\hline NWT & 2009-11 & No & $12,200^{2}$ & More steps than NF & No change \\
\hline$B C$ & 2009-11 & Implemented in 2008 & $12,100^{2}$ & $\begin{array}{l}\text { More steps than NF, PEI, NS, NB } \\
\text { Fewer steps than NU }\end{array}$ & No change \\
\hline MB & 2009-11 & Implemented in 2008 & $12,100^{2}$ & More steps than NF, PEI, NS, NB & No change \\
\hline ON & 2009-11 & Implemented in 2005 & $11,700^{2}$ & $\begin{array}{l}\text { More steps than NF Fewer } \\
\text { steps than NU }\end{array}$ & No change \\
\hline Canadian average & 2009-11 & No national policy & 11,600 & $\mathrm{n} / \mathrm{a}$ & Not reported \\
\hline$A B$ & 2009-11 & Implemented in 2005 & $11,500^{2}$ & Fewer steps than NU & No change \\
\hline SK & 2009-11 & Implemented in 2010 & $11,500^{2}$ & Fewer steps than NU & $\begin{array}{l}\text { Significant decline } \\
\text { compared to 2005-07 }\end{array}$ \\
\hline QC & 2009-11 & No & $11,400^{2}$ & Fewer steps than NU & No change \\
\hline NB & 2009-11 & No & $11,200^{2}$ & Fewer steps than MB, BC, YK, NU & No change \\
\hline PEI & 2009-11 & No & $11,200^{2}$ & Fewer steps than MB, BC, NU & No change \\
\hline NS & 2009-11 & No & $11,100^{2}$ & Fewer steps than $M B, B C, Y K, N U$ & No change \\
\hline NF & 2009-11 & No & $10,800^{3}$ & $\begin{array}{l}\text { Fewer steps than } \mathrm{ON}, \mathrm{MB}, \mathrm{BC} \text {, } \\
\text { YK, NWT, NU }\end{array}$ & No change \\
\hline
\end{tabular}

CANPLAY assessed the mean number of steps taken daily by Canadian children aged 5-19. Children wore the pedometer for 7 consecutive days [115]. Approximately 20,000 children were randomly selected and recruited in 2009-11 [115].

Provinces are listed in order from most to least steps taken.

AB: Alberta; BC: British Columbia; MB: Manitoba; SK: Saskatchewan; NB: New Brunswick; NF: Newfoundland and Labrador; NWT: Northwest Territories; NS: Nova Scotia; NU: Nunavut; PEl: Prince Edward Island; OC:

Quebec; YK: Yukon.

Data in Nunavut were collected using a different methodology [114,115].

${ }^{2}$ Not significantly different from the Canadian average of 11,600 steps per day [114].

${ }^{3}$ Significantly lower than the Canadian average of 11,600 steps per day $(p<0.05)[114]$ 
students have been accorded substantial autonomy in determining the format in which PA is to be provided in schools. When adhered to, flexible delivery of PA opportunities positively impacts children's PA and health outcomes [89-91,117]. Flexibility in implementation was important in minimizing initial resistance to DPA policies in $A B$ [56], likely because it allowed DPA to take place with minimal displacement of time normally dedicated to academic pursuits. Flexible PA delivery can also reinforce the message to children that PA can be incorporated throughout their daily activities, and in a variety of locations. These schemes are also open to abuse, however, as they can lead to inconsistent and/or suboptimal policy implementation [118], and in BC led to falsification of student PA records in some cases [119]. Moreover, they may complicate attempts to monitor and enforce compliance since it may be less clear what constitutes 'proper' implementation.

A strong and consistent international body of knowledge regarding the positive benefits of PA for child health existed prior to the emergence of Canadian DPA policies, and all provinces cited this evidence as a rationale for their DPA policies. However, whereas evidence may have informed the decision to adopt DPA policies, it is less clear the extent to which evidence informed the specific provisions of each one. Some policies coincided with national recommendations at the time they were developed (e.g. the 2002 Canadian PA Guidelines for Children and Youth focused on MVPA and allowed short bouts of activity), while others did not (e.g. some policies did not focus on MVPA and required sustained PA) [120,121]. Moreover, given that policies covered only up to one third of the 90 minutes of PA children were recommended to accumulate at that time $[120,121]$, children would have had to obtain the majority of their PA outside of school hours. Similarly in the US, only $35 \%$ of the PE-related legislation enacted between 2000 and 2007 contained one or more evidence-based statements [122]. Scientific evidence is only one factor policymakers consider during their deliberations [123,124], and thus these other factors may have superseded evidentiary concerns in some cases.

\section{Policy context \\ Adoption and diffusion}

At a broad level, policy diffusion is the phenomenon whereby one government's policy decisions are influenced by another's [39]. Given the interconnected nature of policy networks, policy diffusion is a relatively common phenomenon, and one that is structured by the characteristics and capacities of adopters, their political contexts and the nature of the policies themselves [39]. In the case of DPA policies in Canada, patterns of adoption are consistent with 3 small 'waves' of adoption, with $\mathrm{AB}$ and $\mathrm{ON}$ leading the way, followed by $\mathrm{MB}$ and $\mathrm{BC}$, and later SK. Notably, however, each province introduced a somewhat novel policy. Thus, although the concept of DPA policies diffused among some Canadian provinces, it is not clear to what extent the content of their respective policies diffused. This finding is consistent with the notion of re-invention, or the degree to which an innovation evolves during the course of its adoption and implementation [45]. Re-invention acknowledges that innovations are not fixed entities, nor are adopters passive recipients of new ideas [45]. Instead, adopters purposefully interact with, and actively modify new ideas to better fit their contexts [45]. In the current instance, considerable re-invention occurred as adoption proceeded, which may reflect factors such as contextual tailoring of policies or learning from the experiences of earlier adopters $[125,126]$. Thus, although they are not recognized as chronological innovators, later adopters did exhibit innovative behaviors through re-inventing earlier policies.

Adopter characteristics are among the most important determinants of diffusion. Earlier adopters tend to be more cosmopolitan, are more willing to take risks, are larger and better resourced, and have more extensive social networks [37,45]. Moreover, geographical diffusion models suggest distance is a critical factor, as policy adoption tends to occur later in more distal locations $[38,126]$. On a broad level, these qualities describe the adopters in this study, as adopters were geographically clustered within central and western Canada and, with the exception of Quebec, were the most populous and affluent in the nation (although Quebec is also large, relatively affluent and centrally located, in the interests of preserving its cultural heritage Quebec often acts independently of the rest of Canada) $[106,107]$. Implementation of DPA policies required additional human, financial and material resources that were already constrained within schools, and thus, notwithstanding the exceptional circumstances of Quebec, it is not surprising that the first 5 provinces to adopt DPA policies were the relatively affluent and most populous provinces that could better cope with risk and which, by virtue of their location, maintained closer connections with each other. By contrast, later adopters tend to be more skeptical of new ideas and require stronger evidence of success prior to adoption [45]. For this reason, subsequent 'waves' of DPA policy adoption may not occur until evidence substantively demonstrates policy success via positive change in health or other outcomes.

The concept of innovativeness refers to whether an adopter is early in adopting an innovation relative to other members of a social system [45]. Although Diffusion of Innovations theory sets forth 5 adopter categories, the framework acknowledges that innovativeness is more appropriately conceived as a continuous variable, 
with no sharp breaks between adopter categories [45]. Moreover as we have indicated, policy strength and implementation can vary substantially within adopter categories, potentially contributing to important variations in policy outcomes. Therefore, the current classifications represent simplifications based on theoretical constructs, and may not be optimal. For instance, although BC did not adopt DPA policies until 2008, the province piloted and widely disseminated an internationally recognized, successful model of DPA as early as 2003 through Action Schools! BC [88-91,96], and was the first province to mandate DPA at the high school level. BC was also among the first to develop nutrition guidelines for schools and recreational facilities, to develop a fruit and vegetable program for schools, and to institute a children's fitness tax credit [127-129]. Thus, although it was slower to commit to a DPA policy than some other provinces, the province of $\mathrm{BC}$ may nevertheless be more innovative with respect to child health than the current classification suggests. Future studies could integrate other frameworks to provide a more nuanced perspective of adopter characteristics.

Diffusion of one type of policy can also stimulate diffusion of other related policies, and at other levels. In Canada, the proportion of schools with daily PE policies increased from $35 \%$ in 2006 to $55 \%$ in 2011 [130]. Compared to the national average, in 2011, schools in the western provinces and ON (i.e. DPA adopters) were more likely to have daily PE policies, and schools in the west were more likely to have fully implemented these policies [130]. These geographic and temporal trends suggest that DPA policies may have contributed to diffusion of daily PE policies at the school level, as schools attempted to comply with provincial DPA policies. Evidence of diffusion of PE policies from the state to the school district level has also been documented in the US $[27,40]$.

Although this study focused on diffusion of policies within a Canadian context, examination of international trends is also relevant. Introduction of DPA policies in Canada coincided with a concurrent increase in schoolbased DPA policies in the US, with 4 policies enacted in 2005, 4 in 2006-08 and 6 in 2009-11 [50]. Although not captured in the previous analysis, in 2001, the Texas Legislature passed a bill requiring elementary school children to participate in 30 minutes of DPA or 135 minutes of PA weekly [131]. Given these concurrent trends, it is likely that consideration of broader international patterns of DPA policy diffusion is also warranted, as elements of Canadian and US policies, in particular, likely diffused across national borders.

In addition to findings regarding the conditional nature of diffusion, this analysis highlights the reality that policy adoption and diffusion are processes that unfold over the course of many years. As early as 1975, the MB
Physical Education Working Group proposed that all MB schools be required to offer an average of 40 minutes of PE daily, including 20 minutes of vigorous PA [63], while the concept of Quality Daily PE, including provision of daily PA, was endorsed at a federal level in the late 1980s [15]. That the first DPA policy was not adopted until 2003, and that at present only 5 of Canada's 13 provinces/territories have implemented DPA policies exemplifies the lengthy nature of policy cycles, which can span several decades $[38,132]$. In all cases of policy adoption it was not a single event, but rather a series of related events that unfolded over time and built momentum for change that ultimately led each province to develop DPA policies.

\section{Policy evaluation: Discussion of the systematic review}

Policy evaluation is essential to justify ongoing implementation and can inform critical adjustments to improve policy impact. With the exception of SK, all of the provincial DPA policies have undergone some form of formal evaluation, as described below.

\section{Implementation}

The impact of school-based DPA policies ultimately depends upon the level of, quality and fidelity of implementation, however it is difficult to evaluate the extent of policy implementation due to the variety of measures used across studies and the flexibility inherent within each of the policies. At the school-level, $\geq 80 \%$ of ON schools reported taking action with respect to DPA policy implementation (defined as meeting the recommendations in several, but not all areas), however few $(\leq 20 \%)$ reported consistently meeting or exceeding recommendations $[133,134]$. At the teacher-level in ON, only $16 \%$ reported always conducting DPA on days when PE was not scheduled [135], while at the student-level, $49 \%$ received DPA each school day [136]. The number of schools included in each of these studies was small, however, ranging from 18 to 37. Among 476 schools surveyed in BC, self-reported implementation of DPA policies was $65 \%, 56 \%$ and $51 \%$ for grades 6,8 and 10, respectively [137]. Thus, data are consistent with moderate, but inconsistent implementation of DPA policies in schools, possibly as a result of the low to moderate strength of provincial-level policies and the lack of monitoring. Variation in implementation has the potential to worsen health disparities if better-resourced schools implement DPA policies to a greater extent, and thus assessment of the level of DPA implementation and developing strategies to improve compliance remain ongoing priorities.

A consistent finding across studies that have examined implementation of DPA policies in Canada $[66,119,135]$, and provision of PA/PE in schools in general $[17,23,89,118$, 138-144], is that PA-related goals may be difficult to achieve due to the additional time required to implement them. 
The use of standardized testing to assess the quality of educational instruction and student achievement has led to a prioritization of teaching in academic subjects [21,23,131, 139]. According to Amis et al. [23], this culture of 'academic achievement' has led to a marginalization and devaluing of PE in schools, and may in large measure be responsible for suboptimal implementation of school-based PE/PA policies. In light of overburdened school schedules, it is particularly problematic that DPA is often unscheduled, unstructured and not monitored [135,138]. In this context, DPA may easily be displaced in favor of academic pursuits that educators may perceive to be higher priority [23]. Integrating DPA into the curriculum and providing supportive resources, clear expectations and performance standards might help to avoid this outcome, such that PA becomes a normative and valued aspect of the school day [17]. Moreover, given that PA does not compromise, and may even improve academic performance among school-aged children [31-35], positioning DPA as a strategy to improve student academic achievement may increase support for policy adoption and implementation.

\section{Impact}

In ON, findings of a positive relationship between frequency of DPA and objectively measured overall PA and minutes of MVPA among elementary students in a very small sample of 18 schools are encouraging, however no child achieved the policy goal of $\geq 20$ minutes of sustained MVPA, with the average PA bout lasting just 7.1 minutes [136]. The efficacy of the policy was, however, supported by findings showing that students who participated in DPA 5 days/week achieved higher total PA, the intensity of their PA was greater, and they accumulated more minutes of MVPA on school days and during the school day compared to students who participated in DPA $<5$ days/ week [136]. These results differ from a subsequent paper from the same study which showed that students in schools where administrators reported being in the 'action' phase of DPA implementation did not spend more time in light-to-vigorous PA compared to students from schools in the 'initiation' phase [133]. Similarly, implementation of DPA in ON was not associated with student self-reported PA or BMI in 30 elementary schools [134,145-147]. Differences across studies likely relate to the various exposure and outcome variables considered, and the small number of schools examined.

Findings in MB of a decline in PA as students progressed from grades 9-12 following implementation of the MB PE/Health Education curricula (including DPA for grades 11-12) are similarly difficult to interpret [148]. Given that PA levels decline as children transition to adolescence and adulthood [149-155], it is possible that MB's PE policy slowed this decline, however, as there was no control group, it is not clear what the students' PA trajectories would have been in the absence of the policy. Furthermore, the study was conducted in the context of a provincial PE/Health Education policy which only mandated DPA for students in grades 11 and 12 in the form of 55 hours of self-reported MVPA in each of 2 semesters. Thus, an increase in PA would not necessarily be expected in this context, and findings may point to important limitations of the policy. The slower rate of decline in PA among children attending low socioeconomic status schools is noteworthy, and suggests the MB policy may ameliorate disparities in PA [148].

In $\mathrm{BC}$, schools were more likely to meet the recommended amount of 150 minutes/week of PE for grade 6 students, and to provide more minutes of PE to grade 8 and 10 students following implementation of DPA policies, however the impact on children's PA levels was not assessed [137]. Positive impacts of Action Schools! $\mathrm{BC}$ on student PA and health outcomes have already been demonstrated [89-91], and thus it will be important to determine whether BC's DPA policy provides additional benefits. Impact of the $A B$ and $S K$ policies has not been assessed, however data from the Canadian Fitness and Lifestyle Research Institute [114] suggest that provincial DPA policies have not significantly increased school-aged children's PA levels in any of the Canadian provinces. Notably, however, these data represent the PA levels of all school-aged children, whereas most provincial DPA policies only apply to a subset of school-aged children.

Overall, findings indicate that Canadian DPA policies, as currently implemented, have had little to no impact on school-aged children's PA levels or BMI; although given the paucity of studies and their limitations, it is too early to draw definitive conclusions as to their efficacy, or to distinguish among relatively less and more efficacious policies. These tentative findings must also be considered in light of the fact that policy implementation was moderate in the $\mathrm{ON}$ and BC-based studies, and that there may be substantial variation among schools in strategies used to implement DPA policies [119]. The time frame for assessment relative to policy implementation must also be considered, as the effects of policy may take many years or decades to materialize $[38,132]$. Forthcoming findings related to policy impact in $\mathrm{ON}$ may help to inform more robust conclusions in this respect.

These findings differ from those of a systematic review of school-based PA policies in the US. Similar to our study, outcomes for only a small number of policy reforms were reviewed, however in that review schoolbased PA policies appeared effective in increasing youth PA levels [36]. Importantly, of the 3 studies that assessed impact of PA policies, none used objective measures to assess change in children's PA levels from pre- to post- 
policy implementation [36]. Differences among the populations examined (e.g. age, sex, socioeconomic status), in assessment tools and in specific outcomes examined must also be considered. A recent study that used objective measures to examine impact of a policy in Boston schools to promote 150 minutes/week of MVPA found that the policy led to a significant increase of $3.9 \mathrm{mi}$ nutes/day of MVPA among elementary school children [156]. In addition, several studies that have embedded DPA within broader comprehensive school health initiatives have effectively increased children's PA levels $[91,157]$, suggesting that DPA policies might prove more effective when implemented within this context.

\section{Strengths and limitations}

A multiple case history approach allowed us to study policy adoption and diffusion not as events, but as processes that unfolded over time, providing a rich perspective that could not have been achieved through quantitative, survey-based methodology. A systematic review of the evidence concerning DPA policies offered rich contextualization of the case histories presented. The thorough and extensive nature of our searches, follow-up of all relevant references, wide diversity in the types of documents examined, convergence of findings from different sources, and involvement of multiple reviewers lends credibility to the findings, and suggests we have captured a broad and diverse perspective of the factors that influenced adoption and diffusion of Canadian DPA policies. Nevertheless, this analysis was restricted to a review of web-based, publicly available documents, and thus we may have missed older documents less likely to be posted on the internet. The history of DPA legislation is relatively recent, however, and we were still able to identify historically influential documents through reference lists. The number and type of documents available in each of the provinces was beyond our control, and may have influenced our findings. We focused on retrieving documents at a provincial level, however activities at other levels were also likely influential, but were outside the scope of the current analysis. We did not evaluate the quality of the studies included in the systematic review as there are no tools capable of providing a fair assessment of the quality of natural experiments [36]. Although generalizability is unclear, these case studies provide contextual details useful for assessing generalizability of findings to other contexts.

Although our case histories showed how DPA policies progressed from conception to implementation, it was often not possible to discern the rationale for specific policy provisions (e.g. why MB only mandated DPA for grades 11-12). Review of internal documents and/or interviews with key stakeholders may provide additional insight into the processes surrounding adoption and diffusion of DPA policies, and we are currently conducting key informant interviews in this respect. These data may uncover other influential factors less likely to be discussed in documents, such as the role of policy champions. Conversely, key informants may not be fully aware of the rich and extensive history of efforts to embed health promotion within schools in their respective jurisdictions, and therefore together these analyses will provide a comprehensive and compelling summary of the processes underlying adoption and diffusion of DPA policies in Canada. Given that Diffusion of Innovations theory focusses primarily on the characteristics of innovations and adopters rather than on their political, social and economic contexts, additional explanatory frameworks may be integrated to describe these data.

\section{Conclusion}

This is the first study to collate comprehensive national data with respect to adoption, diffusion, implementation and impact of school-based DPA policies. This study detailed the history and current status of Canadian DPA policies, highlighting the conditional nature of policy adoption and diffusion, and describing policy and adopter characteristics and political contexts that shaped policy trajectories. Findings point to key levers that may have led to some provinces being relatively earlier in adopting DPA policies. An understanding of the conditions associated with successful policy adoption and diffusion can help to identify receptive communities and contexts in which to pioneer novel legislative solutions to the problem of inactivity among children, and is critical to inform efforts to catalyze and accelerate diffusion of health promoting policies in Canada and internationally. However, ensuring implementation of efficacious DPA policies is as important as adopting them. By reviewing evidence regarding implementation and impact of such policies, this study can inform useful amendments to existing policies, and help to strengthen provisions within future legislation. Findings also point to specific gaps within the currently available literature that provide direction for future studies.

Policy making is admittedly a controversial and complex endeavor. Current PA practices in schools are the product of a myriad of policies enacted over several decades. Thus, it may take decades to reverse entrenched policies that bound PA in the school environment, and to establish school communities in which PA is a normative and valued aspect of the school day. Adoption and diffusion of efficacious and effective policies are essential first steps in reshaping PArelated social norms in health-promoting directions. However, the potential of DPA policies is currently constrained by an education system that focuses strongly on academic achievement. To overcome these and others barriers, provinces should integrate DPA within current curricula and monitor policy implementation. Furthermore, the potential benefits of PA on academic outcomes should be emphasized. Investigation of adoption, implementation and impact of DPA policies remains an ongoing priority, both to inform 
policy development, and because sound evidence of policy efficacy and effectiveness can accelerate policy diffusion. Such studies should ideally be structured as natural experiments. Policy, however, is not a panacea, and school-based DPA policies alone will not be sufficient to enable children to meet PA recommendations. Opportunities for intervention are numerous, and thus policies must be complemented by dietary and other PA-related interventions in a variety of settings.

\section{Additional file}

Additional file 1: Database search strategy for systematic review.

\section{Competing interests}

The authors declare that they have no competing interests.

\section{Authors' contributions}

DLO: study design, data collection, analysis, interpretation, wrote the manuscript; EJC: data collection, analysis, interpretation, edited the manuscript; KDR: study design, edited the manuscript; CIJ: study design, data interpretation, edited the manuscript. All authors read and approved the final manuscript.

\section{Acknowledgements}

The authors are grateful to Robin Featherstone for performing the literature searches. This study was supported by the Canadian Partnership Against Cancer through a Coalitions Linking Actions and Science for Prevention grant. The funder had no role in study design, in collection, analysis and interpretation of the data, in writing the manuscript or in the decision to submit it for publication.

\section{Author details \\ ${ }^{1}$ Centre for Physical Activity and Nutrition Research, School of Exercise and Nutrition Sciences, Deakin University, 221 Burwood Highway, Burwood, VIC 3125, Australia. ${ }^{2}$ School of Public Health, 3-300 Edmonton Clinic Health Academy, University of Alberta, 1140587 Avenue, Edmonton, AB T6G 1C9, Canada.}

Received: 9 December 2014 Accepted: 19 March 2015 Published online: 15 April 2015

\section{References}

1. Janssen I, Leblanc AG. Systematic review of the health benefits of physical activity and fitness in school-aged children and youth. Int J Behav Nutr Phys Act. 2010;7:40.

2. Canadian physical activity guidelines for children 5-11 years. [http://csep.ca/ english/view.asp? $\mathrm{x}=804]$

3. Canadian physical activity guidelines for youth 12-17 years. [http://csep.ca/ english/view.asp?x=804]

4. Physical activity guidelines for Americans. [http://www.health.gov/ paguidelines/pdf/paguide.pdf]

5. Directly measured physical activity of Canadian children and youth, 2007 to 2011. [http://www.statcan.gc.ca/pub/82-625-x/2013001/article/11817-eng.htm]

6. Hohepa M, Schofield G, Kolt GS. Physical activity: what do high school students think? J Adolesc Health. 2006;39(3):328-36.

7. Humbert ML, Chad KE, Spink KS, Muhajarine N, Anderson KD, Bruner MW, et al. Factors that influence physical activity participation among high- and low-SES youth. Qual Health Res. 2006;16(4):467-83.

8. Veugelers PJ, Schwartz ME. Comprehensive school health in Canada. Can J Public Health. 2010;101 Suppl 2:S5-8.

9. Hobin EP, Leatherdale ST, Manske SR, Burkhalter R, Woodruff SJ. A multilevel examination of school and student characteristics associated with physical education class enrollment among high school students. J Sch Health. 2010;80(9):445-52.

10. Hobin E, Leatherdale S, Manske S, Dubin J, Elliott S, Veugelers P. A multilevel examination of factors of the school environment and time spent in moderate to vigorous physical activity among a sample of secondary school students in grades 9-12 in Ontario, Canada. Int J Public Health. 2012;57(4):699-709.
11. Myers L, Strikmiller PK, Webber LS, Berenson GS. Physical and sedentary activity in school children grades 5-8: the Bogalusa Heart Study. Med Sci Sports Exerc. 1996;28(7):852-9.

12. Lowry R, Lee SM, Fulton JE, Demissie Z, Kann L. Obesity and other correlates of physical activity and sedentary behaviors among US high school students. J Obes. 2013;2013:276318.

13. Nettlefold L, McKay HA, Warburton DE, McGuire KA, Bredin SS, Naylor PJ. The challenge of low physical activity during the school day: at recess, lunch and in physical education. Br J Sports Med. 2011;45(10):813-9.

14. Janzen $\mathrm{H}$. Daily physical education for K-12: is government legislation in sight? Phys Health Educ J. 2003;69(4):4-10.

15. Quality daily physical education. [http://www.phecanada.ca/75thanniversary/ e/past/documents/N53N6QDPEbornJune91987.pdf]

16. Allison KR, Adlaf EM. Structured opportunities for student physical activity in Ontario elementary and secondary schools. Can J Public Health. 2000;91(5):371-5.

17. Dwyer JJ, Allison KR, Barrera M, Hansen B, Goldenberg E, Boutilier MA. Teachers' perspective on barriers to implementing physical activity curriculum guidelines for school children in Toronto. Can J Public Health. 2003;94(6):448-52.

18. Health and Physical Education Council. Active Living - Physical Education for the 21st Century. A position paper of the Health and Physical Education Council of the Alberta Teachers' Association. 1984. http://hpec.teachers.ab. ca/SiteCollectionDocuments/Position_Papers/HPEC\%20Position\%20Paper\% 20-\%20Active\%20Living\%20-\%20Physical\%20Education\%20for\%20the\% 2021st\%20Century.pdf.

19. Centers for Disease C, Prevention. Participation in high school physical education-Ontario, Canada, 1999-2005. MMWR Morb Mortal Wkly Rep. 2007:56(3):52-4

20. Dwyer JJ, Allison KR, LeMoine KN, Adlaf EM, Goodman J, Faulkner GE, et al. A provincial study of opportunities for school-based physical activity in secondary schools. J Adolesc Health. 2006;39(1):80-6.

21. Choices, changes and challenges: curriculum and instruction in the NCLB era. [http://www.cep-dc.org/displayDocument.cfm?DocumentID=312]

22. Strained Schools Face Bleak Future. Districts Foresee Budget Cuts, Teacher Layoffs, and a Slowing of Education Reform Efforts. [file:///C:/Users/dwilkins/ Downloads/KoberRentner_Report_StrainedSchools_063011.pdf]

23. Amis JM, Wright PM, Dyson B, Vardaman JM, Ferry H. Implementing childhood obesity policy in a new educational environment: the cases of Mississippi and Tennessee. Am J Public Health. 2012;102(7):1406-13.

24. Magnusson RS. What's law got to do with it part 1: A framework for obesity prevention. Aust New Zealand Health Policy. 2008;5:10.

25. Slater SJ, Nicholson L, Chriqui J, Turner L, Chaloupka F. The impact of state laws and district policies on physical education and recess practices in a nationally representative sample of US public elementary schools. Arch Pediatr Adolesc Med. 2012;166(4):311-6.

26. Perna FM, Oh A, Chriqui JF, Masse LC, Atienza AA, Nebeling L, et al. The association of state law to physical education time allocation in US public schools. Am J Public Health. 2012;102(8):1594-9.

27. Chriqui JF, Eyler A, Carnoske C, Slater S. State and district policy influences on district-wide elementary and middle school physical education practices. J Public Health Manag Pract: JPHMP. 2013;19(3 Suppl 1):S41-8.

28. Taber DR, Chriqui JF, Perna FM, Powell LM, Slater SJ, Chaloupka FJ. Association between state physical education (PE) requirements and PE participation, physical activity, and body mass index change. Prev Med. 2013;57(5):629-33.

29. Cawley J, Meyerhoefer C, Newhouse D. The impact of state physical education requirements on youth physical activity and overweight. Health Econ. 2007;16(12):1287-301.

30. Sanchez-Vaznaugh EV, Sanchez BN, Rosas LG, Baek J, Egerter S. Physical Education Policy Compliance and Children's Physical Fitness. Am J Prev Med. 2012:42(5):452-9.

31. Singh A, Uijtdewilligen L, Twisk JW, van Mechelen W, Chinapaw MJ. Physical activity and performance at school: a systematic review of the literature including a methodological quality assessment. Arch Pediatr Adolesc Med. 2012;166(1):49-55.

32. Trost SG, van der Mars H. Why we should not cut P.E. Educ Leadersh. 2009;67(4):60-5

33. Trudeau F, Shephard RJ. Physical education, school physical activity, school sports and academic performance. Int J Behav Nutr Phys Act. 2008;5:10.

34. Rasberry CN, Lee SM, Robin L, Laris BA, Russell LA, Coyle KK, et al. The association between school-based physical activity, including physical education, and 
academic performance: a systematic review of the literature. Prev Med. 2011;52 Suppl 1:S10-20.

35. Ahamed Y, Macdonald H, Reed K, Naylor PJ, Liu-Ambrose T, McKay H. School-based physical activity does not compromise children's academic performance. Med Sci Sports Exerc. 2007;39(2):371-6.

36. Robertson-Wilson JE, Dargavel MD, Bryden PJ, Giles-Corti B. Physical activity policies and legislation in schools: a systematic review. Am J Prev Med. 2012;43(6):643-9.

37. Shipan CR, Volden C. The mechanisms of policy diffusion. Am J Polit Sci. 2008;52(4):840-57.

38. Nykiforuk C, Eyles J, Campbell H. Smoke-free spaces over time: a policy diffusion study of bylaw development in Alberta and Ontario, Canada. Health Soc Care Community. 2008;16(1):64-74.

39. Shipan CR, Volden C. Policy diffusion: Seven lessons for scholars and practitioners. Public Adm Rev. 2012;72(6):788-96.

40. Taber DR, Chriqui JF, Chaloupka FJ. Association and diffusion of nutrition and physical activity policies on the state and district level(*). J Sch Health. 2012;82(5):201-9.

41. Eyler AA, Nguyen L, Kong J, Yan Y, Brownson R. Patterns and predictors of enactment of state childhood obesity legislation in the United States: 2006-2009. Am J Public Health. 2012;102(12):2294-302.

42. Boehmer TK, Brownson RC, Haire-Joshu D, Dreisinger ML. Patterns of childhood obesity prevention legislation in the United States. Prev Chronic Dis. 2007;4(3):A56

43. Boehmer TK, Luke DA, Haire-Joshu DL, Bates HS, Brownson RC. Preventing childhood obesity through state policy. Predictors of bill enactment. Am J Prev Med. 2008;34(4):333-40.

44. Freudenberg N, Bradley SP, Serrano M. Public health campaigns to change industry practices that damage health: an analysis of 12 case studies. Health Educ Behav. 2009;36(2):230-49.

45. Rogers E. Diffusion of Innovations. 5th ed. New York: Free Press; 2003.

46. Quick Law. [http://www.lexisnexis.ca/en-ca/home.page]

47. Prevention policies directory. [http://www.partnershipagainstcancer.ca/2013/11/14/ prevention-policies-directory-supports-change-at-the-local-level-to-improve-thelives-of-canadians/]

48. Mersky RM. Fundamentals of legal research. 8th ed. New York: Foundations Press; 2002.

49. Arksey H, O'Malley L. Scoping studies: towards a methodological framework. Int J Soc Res Methodol. 2005:8(1):19-32.

50. Carlson JA, Sallis JF, Chriqui JF, Schneider L, McDermid LC, Agron P. State policies about physical activity minutes in physical education or during school. J Sch Health. 2013;83(3):150-6.

51. Highlights of the HPEC History and Accomplishments. [http://www.hpec.ab. ca/history]

52. Health and Physical Education Council: Time allocation for physical education programs in Alberta schools. 1984. http://hpec.teachers.ab.ca/ SiteCollectionDocuments/Position_Papers/HPEC\%20Position\%20Paper\%20-\% 20Time\%20Allocation\%20for\%20PhysEd.pdf.

53. School Come Alive History Notes. [http://www.everactive.org/uploads/files/ Documents/SCA_History.pdf]

54. Alberta Coalition for Healthy School Communities Historical Events Timeline. [http://www.achsc.org/download/2009/Historical\%20Review\%20ACHSC\% 20July\%2009.pdf]

55. Kingdon JW. Agendas, alternatives and public policies. New York: Harper Collins Publishers; 1995.

56. Gladwin CP, Church J, Plotnikoff RC. Public policy processes and getting physical activity into Alberta's urban schools. Can J Public Health. 2008:99(4):332-8

57. Making the Case for a Crucial Role for Physical Activity in the Future of Canada's Health Care System. [http://www.activeliving.ca/pdf/ Romanowfinalreport.pdf]

58. Building on values. The future of health care in Canada. [http://publications. gc.ca/collections/Collection/CP32-85-2002E.pdf]

59. Federal-Provincial-Territorial Conference of Ministers responsible for sport and recreation press release. [http://lin.ca/sites/default/files/attachments/ FederalProvincialTerritorialConferenceOfMinistersPressReleaseFEB181995.pdf]

60. Premier's Advisory Council on Health: A Framework for Reform: Report of the Premier's Advisory Council on Health (Mazankowski Report). Edmonton, AB: Government of Alberta; 2002. http://www.health.alberta.ca/documents/ Mazankowski-Report-2001.pdf.

61. Alberta Future Summit. [http://www.finance.alberta.ca/publications/other/ 2002_0530_future_summit_report.pdf]
62. Every child learns, every child succeeds : report and recommendations. [https://education.alberta.ca/media/413413/commissionreport.pdf]

63. Active Living Task Force Recommendations. [http://lin.ca/sites/default/files/ attachments/activ.pdf]

64. Physical Education Kindergarten to Grade 12. [http://www.education.alberta. ca/teachers/program/pe/programs.aspx]

65. Daily phys. ed. classes to fight obesity. Edmonton Journal. [http://login. ezproxy.library.ualberta.ca/login?url=http://search.proquest.com/docview/ 253034922?accountid=14474]

66. Daily physical activity survey report. [http://education.alberta.ca/media/ 756341/dpasurveyreport.pdf]

67. Robinson DB, Melnychuk NE. Discourse, teacher identify, and the implementation of daily physical activity. J Educ Res. 2008;3:245-57.

68. Ontario Ministry of Education. Daily physical activity in elementary schools, grades 1-8. Policy/program memorandum no. 138. 2005. http://www.edu. gov.on.ca/extra/eng/ppm/138.html.

69. Active 2010. Ontario's sport and physical activity strategy. [http://www.mhp. gov.on.ca/en/active-living/about/active2010-strategy-e.pdf]

70. Foundations for a Healthy School. [http://www.edu.gov.on.ca/eng/ healthyschools/foundations.pdf]

71. Healthy schools condition healthy minds. [http://news.ontario.ca/archive/en/ 2005/10/06/Healthy-Schools-Condition-Healthy-Minds.html]

72. Healthy Weights, Healthy Lives. [http://www.mhp.gov.on.ca/en/heal/ healthy_weights.pdf]

73. Living School Highlight Report. [https://www.ophea.net/sites/default/files/ archive/LS_HighlightReport_Final_130C05.pdf]

74. Six lost years. It's time for action. [http://jongerrardmla.ca/wp-content/ uploads/2014/04/SIX-LOST-YEARS-FINAL-COPY.pdf]

75. Manitoba Education and Training. Kindergarten to Senior 4 Physical Education/Health Education. Manitoba Curriculum Framework of Outcomes for Active Healthy Lifestyles. 2000. http://www.edu.gov.mb.ca/k12/cur/ physhlth/framework/intro.pdf.

76. Healthy Child Manitoba. [http://www.gov.mb.ca/healthychild/about/index. html].

77. Healthy Schools Consultation 2 Report. [http://www.gov.mb.ca/ healthyschools/docs/consult_0107.pdf]

78. Manitoba Physical Activity Action Plan. [http//www.pacm.ca/assets/downloads/ physical\%20activity\%20action\%20plan\%20electronic\%20copy\%202006.pdf]

79. Implementation of Grades 11 and 12 Physical Education/Health Education. A Policy Document. [http://www.edu.gov.mb.ca/k12/docs/policy/imp_pehe/ document.pdf]

80. Healthy Kids Healthy Futures Task Force Report. [http://www.gov.mb.ca/ healthykids/docs/finalreport.pdf]

81. Daily Physical Education and Health Enhancing Physical Activity Position Statement. [http://uwwebpro.uwinnipeg.ca/faculty/pass/kah/webpages/ positionstatement.htm]

82. Province Celebrates Success of in motion Strategy. [http://www. manitobainmotion.ca/news/media/?id=85]

83. In motion physical activity strategy officially launched across Manitoba. [http://www.manitobainmotion.ca/news/media/?id=15]

84. Becoming a healthy school in motion. Introduction package. [http://www manitobainmotion.ca/common/uploads/files/Healthy_Schools_in_motion_ Intro_Package_2011 - English.pdf]

85. Scheduling Kindergarten to Grade 8 Physical Education/Health Education. A Resource for School Administrators. [http://www.edu.gov.mb.ca/k12/cur/ physhlth/scheduling/document.pdf]

86. DASH. Parnering for healthier schools. [http://www.dashbc.ca/about/ourhistory/]

87. An ounce of prevention - A public health rationale for the school as a setting for health promotion: a report of the provincial health officer. [https://www.health.gov.bc.ca/pho/pdf/o_prevention.pdf]

88. Naylor PJ, Macdonald HM, Reed KE, McKay HA. Action Schools! BC: a socioecological approach to modifying chronic disease risk factors in elementary school children. Prev Chronic Dis. 2006;3(2):A60.

89. Naylor PJ, Macdonald HM, Zebedee JA, Reed KE, McKay HA. Lessons learned from Action Schools! BC-an 'active school' model to promote physical activity in elementary schools. J Sci Med Sport / Sports Med Aust. 2006;9(5):413-23.

90. Reed KE, Warburton DE, Macdonald HM, Naylor PJ, McKay HA. Action Schools! BC: a school-based physical activity intervention designed to decrease cardiovascular disease risk factors in children. Prev Med. 2008;46(6):525-31. 
91. Naylor PJ, Macdonald HM, Warburton DE, Reed KE, McKay HA. An active school model to promote physical activity in elementary schools: action schools! BC. Br J Sports Med. 2008;42(5):338-43.

92. School health promotion in British Columbia. [http://www.jcsh-cces.ca/ upload/School\%20Health\%20Promotion\%20in\%20BC\%20-\%202009.pdf]

93. The Case of ActNowBC. [http://www.phac-aspc.gc.ca/publicat/2009/ ActNowBC/section3-partie3-eng.php]

94. The Winning Legacy. A Plan for Improving the Health of British Columbians by 2010. [http://www.bchealthyliving.ca/sites/all/files/BCHLA_Winning_ Legacy_0.pdf]

95. Report of proceedings (Hansard) Select standing committee on health [http://www.leg.bc.ca/cmt/38thparl/session-2/health/hansard/T60427a.htm]

96. A Strategy for Combatting Childhood Obesity and Physical Inactivity in British Columbia. [http://www.leg.bc.ca/cmt/38thparl/session-2/health/ reports/Rpt-Health-38-2-29Nov2006.pdf]

97. Summary of ideas from the Ministry of Education meeting on Daily Physical Activity meeting held June 2, 2008. [http://www.bced.gov.bc.ca/dpa/ resources.htm]

98. School Plus. A Vision for Children and Youth. [http://edadm821.files. wordpress.com/2013/01/schoolplus-final-report.pdf]

99. A physically active Saskatchewan. A strategy to get Saskatchewan people in motion! [http://www.publications.gov.sk.ca/details.cfm?p=10336]

100. Healthier places to live, work and play. A population health promotion strategy for Saskatchewan. [http://www.health.gov.sk.ca/population-healthstrategy]

101. 2010. [http://www.saskatchewaninmotion.ca/parents-leaders/active-schools/ daily-physical-activity]

102. Saskatchewan in motion. [http://67.207.145.11/take-action/join-the-movement]

103. What is quality daily physical education? [http://www.speaonline.ca/qdpe.html]

104. 2009 Active Healthy Kids Canada Report Card on Physical Activity for Children and Youth Saskatchewans Supplement. [http://www.enmouvement.ca/opFichier/active-kids-report-card-7tQQV5srOOVM-13181.pdf]

105. Inspiring movement. Towards comprehensive school community health: Guidelines for physical activity in Saskatchewan schools. [http://www.education. gov.sk.ca/physical-activity/]

106. Gross domestic product, expenditure-based, by province and territory. [http:// www.statcan.gc.ca/tables-tableaux/sum-som/l01/cst01/econ15-eng.htm]

107. Population by year, by province and territory. [http://www.statcan.gc.ca/ tables-tableaux/sum-som/l01/cst01/demo02a-eng.htm]

108. Towards a Healthier Canada - 2013 Progress Report on Advancing the Federal/Provincial/Territorial Framework on Healthy Weights. [http://www.phn-rsp.ca/thcpr-vcpsre-2013/index-eng.php]

109. Bill 44 Healthy Students Act. [http://www.gnb.ca/legis/bill/pdf/55/3/Bill-44.pdf

110. Bill 115 An Act to Amend Chapter 1 of the Acts of 1995-96, the Education Act. [http://nslegislature.ca/legc/bills/60th_2nd/1st_read/b115.htm]

111. Quebec en Forme. [http://www.quebecenforme.org]

112. Quality Daily Physical Education - The facts. [http://www.phecanada.ca/ programs/quality-daily-physical-education/facts]

113. Pan-Canadian Joint Consortium for School Health. Mandate, mission and vision. [http://www.jcsh-cces.ca/index.php/about/mandate-mission-vision]

114. Bulletin 02: Physical activity levels of Canadian children and youth including Provincial Bulletins. [http://www.cflri.ca/node/972].

115. Kids CAN PLAY! Methodology, CANPLAY study. [http://www.cflri.ca/media/ node/995/files/CANPLAY\%20Methodology\%20EN.pdf]

116. Brownson RC, Chriqui JF, Burgeson CR, Fisher MC, Ness RB. Translating epidemiology into policy to prevent childhood obesity: the case for promoting physical activity in school settings. Ann Epidemiol. 2010;20(6):436-44.

117. Lagarde F, LeBlanc C. Policy options to support physical activity in schools. Can J Public Health. 2010;101 Suppl 2:S9-13.

118. Belansky ES, Cutforth N, Delong E, Ross C, Scarbro S, Gilbert L, et al. Early impact of the federally mandated Local Wellness Policy on physical activity in rural, low-income elementary schools in Colorado. J Public Health Policy. 2009;30 Suppl 1:S141-60.

119. Masse LC, Naiman D, Naylor PJ. From policy to practice: implementation of physical activity and food policies in schools. Int J Behav Nutr Phys Act. 2013;10:71.

120. Health Canada and the Canadian Society for Exercise Physiology. Canada's physical activity guide for youth. Cat. No. H39-611/2002-IE. Ottawa, Ont: Minister of Public Works and Government Services Canada; 2002. p. 122.

121. Health Canada and the Canadian Society for Exercise Physiology. Canada's physical activity guide for children. Cat. No. H39-611/2002-2E. Ottawa, Ont: Minister of Public Works and Government Services Canada; 2002.
122. Eyler AA, Brownson RC, Aytur SA, Cradock AL, Doescher M, Evenson KR, et al. Examination of trends and evidence-based elements in state physical education legislation: a content analysis. J Sch Health. 2010;80(7):326-32.

123. Greenhalgh T, Russell J. Evidence-based policymaking: a critique. Perspect Biol Med. 2009;52(2):304-18.

124. Gollust SE, Kite HA, Benning SJ, Callanan RA, Weisman SR, Nanney MS. Use of research evidence in state policymaking for childhood obesity prevention in Minnesota. Am J Public Health. 2014;104(10):1894-900.

125. Hays SP. Patterns of reinvention: The nature of evolution during policy diffusion. Policy Stud J. 1996;24(4):551-66.

126. Glick HR, Hays SP. Innovation and reinvention in state policymaking: theory and the evolution of living will laws. J Polit. 1991;53(3):835-49.

127. Guidelines for Food and Beverage Sales in BC Schools. [http://www.bced. gov.bc.ca/health/healthy_eating/food_guidelines/]

128. Healthier Choices in Vending Machines in B.C. Public Buildings Policy Paper. [http://www.health.gov.bc.ca/healthyeating/pdf/healthier-choices-invending-machines-bc.pdf]

129. Cut Your Taxes with the Children's Fitness Tax Credit. [http://www.bcliving ca/health/cut-your-taxes-with-the-childrens-fitness-tax-credit]

130. Encouraging Active Schools. 2011 Opportunities for Physical Activity at School Survey. [http://www.cflri.ca/pub_page/318]

131. Kelder SH, Springer AS, Barroso CS, Smith CL, Sanchez E, Ranjit N, et al. Implementation of Texas Senate Bill 19 to increase physical activity in elementary schools. J Public Health Policy. 2009;30 Suppl 1:S221-47.

132. Walker JL. The diffusion of innoations among the American states. Am Polit Sci Rev. 1969:63:880-99.

133. Faulkner G, Zeglen L, Leatherdale S, Manske S, Stone M. The relationship between school physical activity policy and objectively measured physical activity of elementary school students: a multilevel model analysis. Arch Public Health. 2014;72(1):20.

134. Leatherdale ST, Manske S, Faulkner G, Arbour K, Bredin C. A multi-level examination of school programs, policies and resources associated with physical activity among elementary school youth in the PLAY-ON study. Int J Behav Nutr Phys Act. 2010;7(1):6

135. Patton I. Teachers' perspectives of the daily physical activity program in Ontario. Phys Health Educ J. 2012;78(1):14-21.

136. Stone MR, Faulkner GE, Zeglen-Hunt L, Bonne JC. The Daily Physical Activity (DPA) policy in Ontario: is it working? an examination using accelerometrymeasured physical activity data. Can J Public Health. 2012;103(3):170-4.

137. Watts AW, Masse LC, Naylor PJ. Changes to the school food and physical activity environment after guideline implementation in British Columbia, Canada. Int J Behav Nutr Phys Act. 2014;11:50.

138. Langille $\mathrm{J}$, Rodgers WM. Exploring the influence of a social ecological model on school-based physical activity. Health Educ Behav. 2010;37(6):879-94.

139. Physical education curriculum review report. [https://www.bced.gov.bc.ca/ $\mathrm{irp} / \mathrm{pdf} /$ reports/pereport.pdf]

140. No Time to Wait: The Healthy Kids Strategy. [http://www.health.gov.on.ca/ en/common/ministry/publications/reports/healthy_kids/healthy_kids.pdf

141. Evenson KR, Ballard K, Lee G, Ammerman A. Implementation of a schoobased state policy to increase physical activity*. J Sch Health. 2009;79(5):231-8. quiz 244-236.

142. Agron P, Berends V, Ellis K, Gonzalez M. School wellness policies: perceptions, barriers, and needs among school leaders and wellness advocates. J Sch Health. 2010;80(11):527-35. quiz 570-522.

143. Mclsaac JL, Read K, Veugelers PJ, Kirk SF. Culture matters: a case of school health promotion in Canada. Health Promot Int. 2013. http://www.ncbi.nlm. nih.gov/pubmed/23945087.

144. Howie EK, Newman-Norlund RD, Pate RR. Smiles count but minutes matter: responses to classroom exercise breaks. Am J Health Behav. 2014:38(5):681-9.

145. Leatherdale ST. A cross-sectional examination of school characteristics associated with overweight and obesity among grade 1 to 4 students. BMC Public Health. 2013;13:982

146. Hobin EP, Leatherdale ST, Manske SR, Robertson-Wilson J. A multileve examination of school and student characteristics associated with moderate and high levels of physical activity among elementary school students (Ontario, Canada). Can J Public Health. 2010;101(6):495-9.

147. Leatherdale ST. School characteristics and physical activity among grade 1-4 students. Am J Health Behav. 2014;38(2):200-7.

148. Hobin E, So J, Rosella L, Comte M, Manske S, McGavock J. Trajectories of objectively measured physical activity among secondary students in Canada 
in the context of a province-wide physical education policy: a longitudinal analysis. J Obes. 2014;2014:958645.

149. Kimm SY, Glynn NW, Kriska AM, Barton BA, Kronsberg SS, Daniels SR, et al. Decline in physical activity in black girls and white girls during adolescence. N Engl J Med. 2002;347(10):709-15.

150. Caspersen CJ, Pereira MA, Curran KM. Changes in physical activity patterns in the United States, by sex and cross-sectional age. Med Sci Sports Exerc. 2000;32(9):1601-9.

151. Nelson MC, Neumark-Stzainer D, Hannan PJ, Sirard JR, Story M. Longitudinal and secular trends in physical activity and sedentary behavior during adolescence. Pediatrics. 2006;118(6):e1627-34.

152. Gordon-Larsen P, Nelson MC, Popkin BM. Longitudinal physical activity and sedentary behavior trends: adolescence to adulthood. Am J Prev Med. 2004;27(4):277-83.

153. Sallis JF. Age-related decline in physical activity: a synthesis of human and animal studies. Med Sci Sports Exerc. 2000;32(9):1598-600.

154. Long MW, Sobol AM, Cradock AL, Subramanian SV, Blendon RJ, Gortmaker SL. School-day and overall physical activity among youth. Am J Prev Med. 2013:45(2):150-7.

155. Troiano RP, Berrigan D, Dodd KW, Masse LC, Tilert T, McDowell M. Physical activity in the United States measured by accelerometer. Med Sci Sports Exerc. 2008:40(1):181-8.

156. Cradock AL, Barrett JL, Carter J, McHugh A, Sproul J, Russo ET, et al. Impact of the Boston Active School Day policy to promote physical activity among children. Am J Health Promot. 2014;28(3 Suppl):S54-64.

157. Vander Ploeg KA, McGavock J, Maximova K, Veugelers PJ. School-based health promotion and physical activity during and after school hours. Pediatrics. 2014;133(2):e371-8.

158. Daily Physical Activity Initiative. [http://education.alberta.ca/teachers/ resources/dpa.aspx]

159. Daily physical activity for children and youth. A review and synthesis of the literature [https://education.alberta.ca/media/318711/ dpa4youth.pdf]

160. Responses to Frequently Asked Questions re: "Implementation of Grades 11 and 12 Physical Education/Health Education: A Policy Document". [http:// www.edu.gov.mb.ca/k12/cur/physhlth/]

161. Manitoba Education. Physical Education/Health Education. Manitoba PE/HE Curriculum Oveniew. 2007. http//wnww.edu.gov.mb.ca/k12/cur/physhlth/ c_overview.html.

162. Daily physical activity. [http://www2.gov.bc.ca/gov/topic.page? id=1AF7BBEAEBD2477CBD8A49676B361ABC]

163. Daily Physical Activity. Kindergarten to Grade 12 Program Guide [http:// www.bced.gov.bc.ca/dpa/pdfs/program_guide.pdf]

164. Alberta Community Development. Alberta Active Living Strategy Discussion Paper. 1998

165. Leatherdale ST. The association between overweight and school policies on physical activity: a multilevel analysis among elementary school youth in the PLAY-On study. Health Educ Res. 2010:25(6):1061-73.

166. Robertson-Wilson JE, Levesque L. Ontario's daily physical activity policy for elementary schools: is everything in place for success? Can J Public Health. 2009;100(2):125-9.

\section{Submit your next manuscript to BioMed Central and take full advantage of:}

- Convenient online submission

- Thorough peer review

- No space constraints or color figure charges

- Immediate publication on acceptance

- Inclusion in PubMed, CAS, Scopus and Google Scholar

- Research which is freely available for redistribution 